Someda $\mathrm{M}$ et al.

\title{
Caspase-8, RIPK1, and RIPK3 Coordinately Regulate Retinoic Acid-Induced Cell
}

\section{Differentiation and Necroptosis}

Masataka Someda, ${ }^{1}$ Shunsuke Kuroki, ${ }^{1,2}$ Makoto Tachibana ${ }^{2}$ and Shin Yonehara ${ }^{1, *}$

${ }^{1}$ Graduate School of Biostudies, Kyoto University, Kyoto 606-8501, Japan.

${ }^{2}$ The Institute for Enzyme Research, The University of Tokushima, Tokushima 770-8503, Japan.

*Correspondence: yonehara@lif.kyoto-u.ac.jp 
bioRxiv preprint doi: https://doi.org/10.1101/156901; this version posted June 28, 2017. The copyright holder for this preprint (which was

not certified by peer review) is the author/funder, who has granted bioRxiv a license to display the preprint in perpetuity. It is made available under aCC-BY 4.0 International license.

Someda M et al.

\section{Abstract}

Caspase-8, which is essential for death receptor-mediated apoptosis, inhibits necroptosis by suppressing the function of RIPK1 and RIPK3 to activate MLKL. We show that knockdown of caspase- 8 expression in embryoid bodies derived from ES cells markedly enhances retinoic acid (RA)-induced cell differentiation and necroptosis, both of which are dependent on Ripk1 and Ripk3. RA treatment obviously enhanced the expression of RA-specific genes having a retinoic acid response element $(R A R E)$ to induce cell differentiation, and induced marked expression of RIPK1, RIPK3 and MLKL to stimulate necroptosis. Caspase- 8 knockdown induced RA receptor (RAR) to form a complex with RIPK1 and RIPK3 in the nucleus, and RAR interacting with RIPK1 and RIPK3 showed much stronger binding activity to RARE than RAR without RIPK1 or RIPK3. In Caspase-8-deficient mouse embryos, expression of RA-specific genes was obviously enhanced. Thus, caspase-8, RIPK1, and RIPK3 regulate RA-induced cell differentiation and necroptosis both in vitro and in vivo. 


\section{Introduction}

Apoptosis is an important physiological cell suicide mechanism essential for normal embryonic development and the maintenance of homeostasis in adult tissues. Caspases, members of the cysteine protease family, play an essential role in the induction of apoptosis (Alnemri, 1997; Chinnaiyan et al., 1997). Two major pathways of mammalian apoptosis are known, a pathway through mitochondria (intrinsic pathway) and a pathway through death receptors (extrinsic pathway) (Green, 2005). Both pathways require the activation of a variety of caspases, which are known to be pro-enzymes activated by cleavage at aspartate residues upon death signaling (Salvesen and Dixit, 1997).

Caspase- 8 was originally identified as an initiator caspase and mainly functions in the death receptor pathway of apoptosis. Upon ligation of a death receptor such as Fas ( Yonehara et al., 1989; Itoh et al., 1991), caspase-8 is recruited to a complex known as a death-inducing signaling complex (DISC) together with other factors including Fas, Fas-associated death domain (FADD) (Muzio et al., 1996). Within the complex, proximity-induced auto-cleavage through homo-oligomerization/dimerization catalytically activates caspase- 8 . The activated caspase- 8 transmits the death signal mainly to executor caspases including caspase-3, which then cleave various cellular proteins to complete the apoptosis-inducing process (Thornberry and Lazebnik, 1998). Caspase-8 is unique, with associated critical activities not only to induce 
bioRxiv preprint doi: https://doi.org/10.1101/156901; this version posted June 28,2017 . The copyright holder for this preprint (which was

not certified by peer review) is the author/funder, who has granted bioRxiv a license to display the preprint in perpetuity. It is made available under aCC-BY 4.0 International license.

Someda $\mathrm{M}$ et al.

apoptosis but also to suppress death receptor-mediated necroptosis ( Varfolomeev et al., 1998;

Oberst et al., 2011). Caspase- 8 inhibits necroptosis by suppressing the function of receptor interacting protein kinase 1 (RIPK1 or RIP1) and RIPK3 (or RIP3) (Hitomi et al., 2008; He et al., 2009; Zhang et al., 2009) to activate MLKL, an executer molecule of necroptosis (Wang et al., 2014). Disruption of caspase-8 (Casp8) expression causes embryonic lethality in mice around embryonic day 11.5 (E11.5) (Varfolomeev et al., 1998; Sakamaki et al., 2002), which is rescued by depletion of Ripk3 or $m l k l$, indicating that the embryonic lethality is caused by activation of necroptosis (Kaiser et al., 2011; Alvarez-Diaz et al., 2016).

Retinoic acid (RA), which is a metabolic product of vitamin A, is a well-established signaling molecule that plays essential roles in vertebrate embryonic body shaping and organogenesis, tissue homeostasis, cell proliferation, differentiation, and apoptosis by regulating the expression of RA-specific target genes (Mark, 2005; Duester, 2008; Rhinn and Dolle, 2012). RA binds to a transcription complex in nucleus, which includes a pair of ligand-activated transcription factors composed of the RA receptor (RAR)-retinoic X receptor (RXR) heterodimer, to induce transcription of RA-specific genes. There are three RAR genes (Rara, Rarb and Rarg) and three RXR genes (Rxra, Rxrb and Rxrg), and the heterodimeric pair binds to a DNA sequence called a retinoic acid-response element (RARE) (Dolle et al., 1989, Mangelsdorf, 1990, Mangelsdorf, 1991). Genes containing RARE in their promoters 
Someda $\mathrm{M}$ et al.

are known to be involved in diverse but interrelated biological processes, such as

embryogenesis, growth, and differentiation (Durand et al., 1992). Following the successful

application of RA in the differentiation therapy of acute promyelocytic leukemia (APL),

regulation of RA signaling was also related to differentiation, proliferation or apoptosis of

tumor cells (Wang and Chen, 2008; Ablain et al., 2014). 


\section{Results}

\section{Knockdown of Caspase-8 Expression Evidently Enhances RA-Induced Cell}

\section{Differentiation}

The roles of caspase- 8 on growth, viability and differentiation were investigated in ES cells by utilizing a tetracycline/doxycycline (Dox)-inducible short hairpin RNA (shRNA) expression (Tet-On) system (Kobayashi and Yonehara, 2009) specific for Casp8 (shCasp8)

(Figure 1A). While Casp8 expression was clearly down-regulated by treatment with Dox in ES cells with the Tet-On shCasp 8 system (Tet-On shCasp 8 ES cells) (Figure 1B), significant effects on neither growth nor viability were observed in the ES cells after treatment with Dox. Furthermore, in vitro neural differentiation induced by embryoid body (EB) formation (Watanabe et al., 2005) was comparable in ES cells irrespective of whether Casp 8 expression was down-regulated or not. Interestingly, however, cell differentiation was remarkably enhanced in EBs derived from Casp 8 KD ES (Casp8 KD ES) cells after 6-day treatment with RA (Figures 1C, Figure 1 - figure supplement 1A). Oct3/4, a marker of undifferentiated cells, was strongly down-regulated in RA-treated EBs derived from Casp 8 KD ES cells (Figure 1D), and the expression levels of neural differentiation markers, Nestin and Tujl, were up-regulated in RA-treated EBs derived from Casp 8 KD ES cells relative to control shGFP 
bioRxiv preprint doi: https://doi.org/10.1101/156901; this version posted June 28,2017 . The copyright holder for this preprint (which was

not certified by peer review) is the author/funder, who has granted bioRxiv a license to display the preprint in perpetuity. It is made available under aCC-BY 4.0 International license.

Someda $\mathrm{M}$ et al.

ES cells (Figure 1E). While the expression level of Casp8 was also up-regulated in the

RA-treated EBs, expression of Casp 8 was almost entirely diminished for the entire time in

Casp8 KD EBs (Figure 1 - figure supplement 1B). Thus, KD of Casp8 expression in ES cells

markedly enhances RA-induced neural differentiation. 


\section{Figure 1}

A

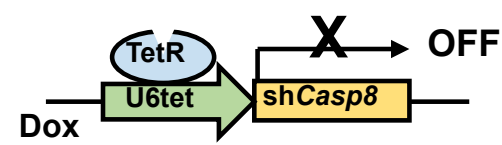

B Tet-On shCasp8 ES
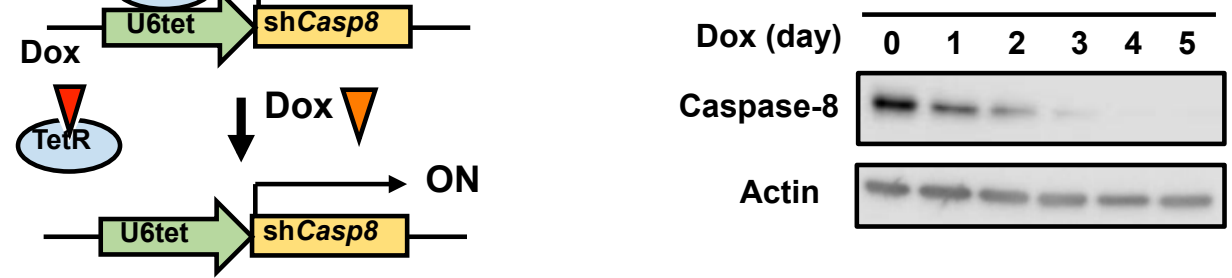

C

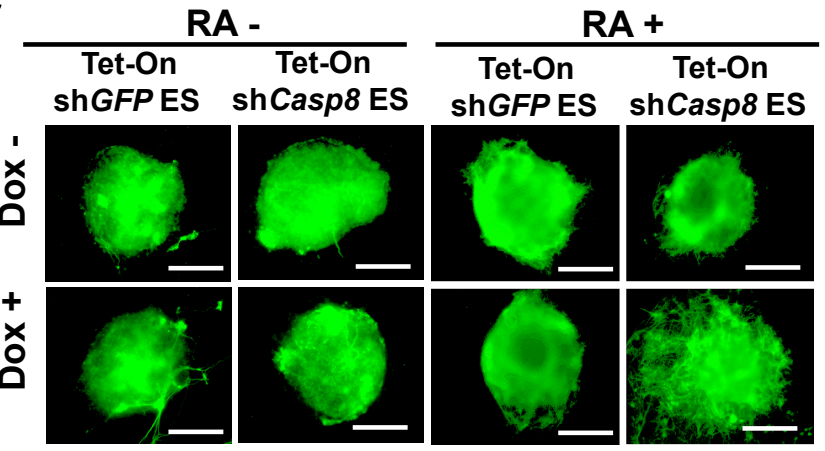

D

$\mathbf{E}$
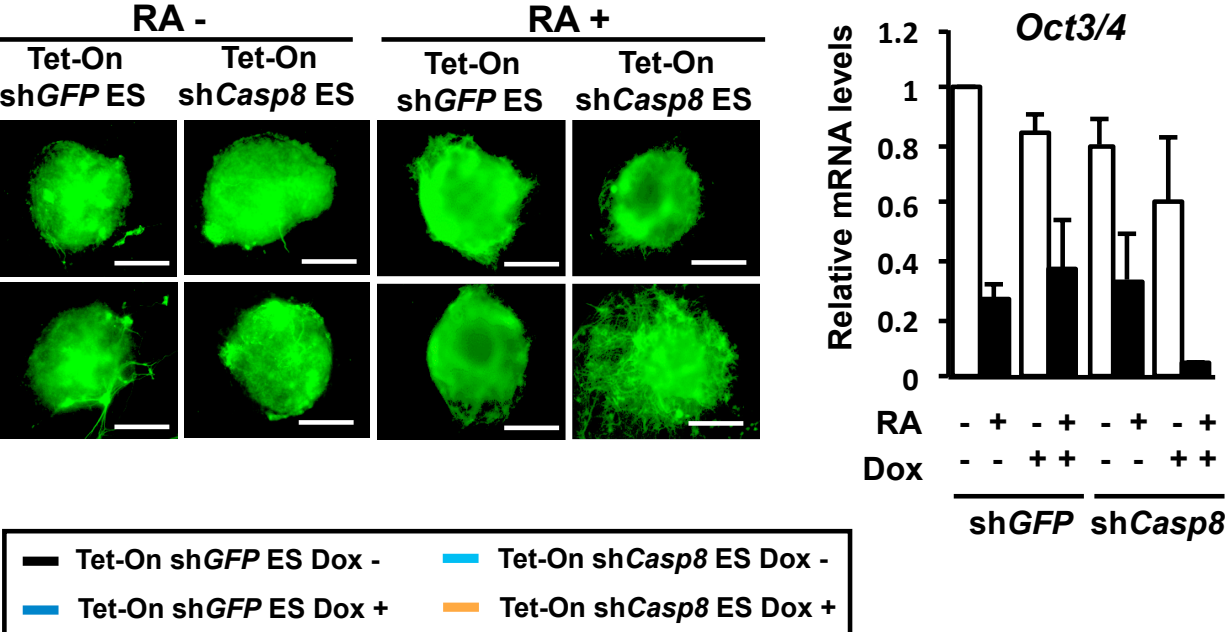

\section{Nestin}
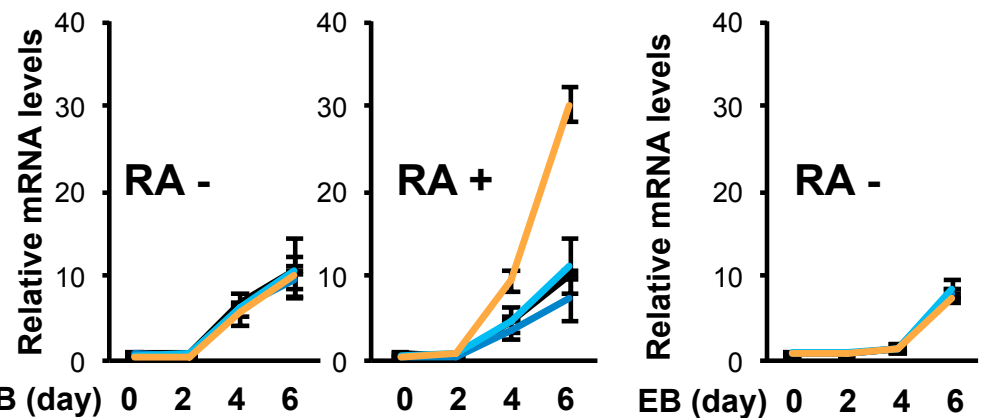

Tuj1

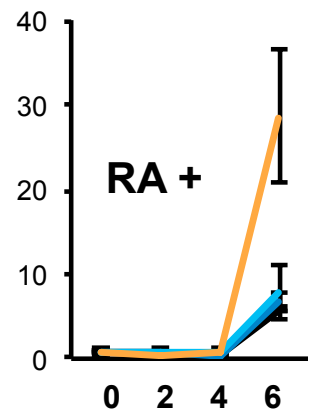




\section{Figure 1 with one supplement}

\section{Knockdown of Casp8 in ES cells enhances RA-induced cell differentiation.}

(A) Dox-inducible (Tet-On) shCasp8-expression system in ES cells. TetR, tetracycline repressor; and U6tet, mouse $U 6$ promoter joining the tetracycline operator.

(B) Validation of induced knockdown of Casp 8 expression in Tet-On shCasp 8 ES cells by western blot analysis after treatment with $1 \mu \mathrm{g} / \mathrm{ml}$ Dox for indicated days.

(C) Neuronal differentiation of Dox $(1 \mu \mathrm{g} / \mathrm{ml})$-treated or -untreated Tet-On $\operatorname{shCasp} 8$ and Tet-On shGFP ES cells was analyzed after 6 days formation of EBs. EBs were treated with or without $1 \mu \mathrm{M}$ RA for last 4 days. Fluorescence microscopy analysis was performed after staining with anti-Tuj1 antibody. Scale bars, $200 \mu \mathrm{m}$.

(D) qRT-PCR analysis of Oct3/4 was carried out using EBs derived from Tet-On shCasp8 and Tet-On shGFP ES cells after 6 days formation of EBs in the presence or absence of 1 $\mu \mathrm{g} / \mathrm{ml}$ Dox. EBs were treated with or without $1 \mu \mathrm{M}$ RA for last 4 days. Representative data are shown as means $\pm \operatorname{SEM}(\mathrm{n}=3)$.

(E) qRT-PCR analysis of Nestin and Tuj 1 was carried out using Tet-On shCasp 8 and Tet-On shGFP ES cells at the indicated times after formation of EBs in the presence or absence of 1 $\mu \mathrm{g} / \mathrm{ml}$ Dox. EBs were cultured with or without $1 \mu \mathrm{M}$ RA for last 4 days. Representative data are shown as means $\pm \operatorname{SEM}(\mathrm{n}=3)$. 
A

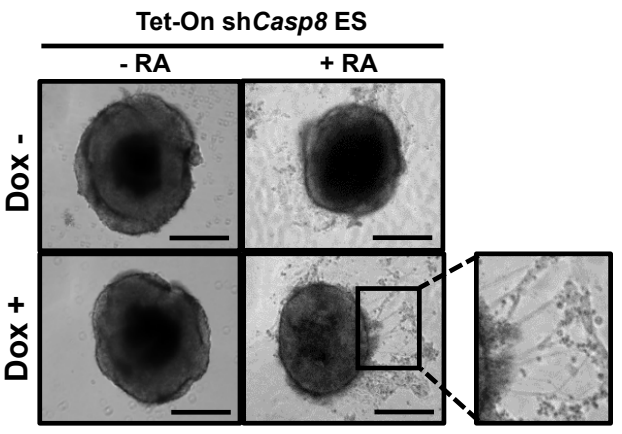

B

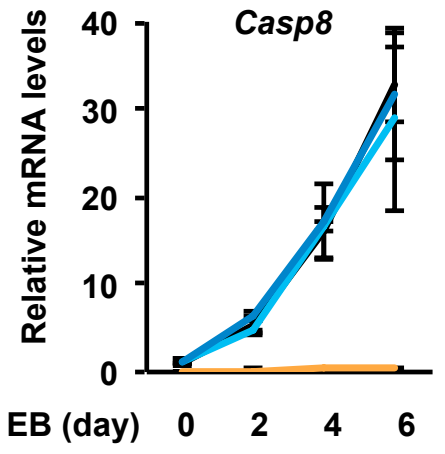

$$
\begin{aligned}
& \text { - Tet-On shGFP ES Dox - } \\
& \text { - Tet-On shGFP ES Dox + } \\
& \text { - Tet-On shCasp8 ES Dox - } \\
& \text { - Tet-On shCasp8 ES Dox + }
\end{aligned}
$$

Figure 1 - figure supplement 1.

RA-induced neuronal differentiation of Tet-On shCasp8 ES cells.

(A) Neuronal differentiation of Dox $(1 \mu \mathrm{g} / \mathrm{ml})$-treated or -untreated Tet-On shCasp 8 ES cells was analyzed under a phase-contrast microscope after 6 days formation of EBs. EBs were treated with or without $1 \mu$ M RA for last 4 days. Scale bars, $200 \mu \mathrm{m}$.

(B) qRT-PCR analysis of Casp-8 in Tet-On shCasp 8 and Tet-On shGFP ES cells at the indicated times after formation of EBs in the presence or absence of $1 \mu \mathrm{g} / \mathrm{ml}$ Dox. EBs were cultured with or without $1 \mu \mathrm{M}$ RA after 2 days formation of EBs. Representative data are shown as means $\pm \operatorname{SEM}(\mathrm{n}=3)$. 
bioRxiv preprint doi: https://doi.org/10.1101/156901; this version posted June 28,2017 . The copyright holder for this preprint (which was

not certified by peer review) is the author/funder, who has granted bioRxiv a license to display the preprint in perpetuity. It is made available under aCC-BY 4.0 International license.

Someda $\mathrm{M}$ et al.

\section{Knockdown of Caspase-8 or Fadd Markedly Enhances RA Signaling}

We then analyzed expression levels of RA-induced genes, Crabp2, Hoxb1, Cyp26al and Rarb, which expressions were under the control of RARs and a RARE in the respective promoter regions of these genes (Rossant et al., 1991; Astrom et al., 1994, Ogura and Evans, 1995; Loudig et al., 2000). Quantitative real time polymerase chain reaction (qRT-PCR) and dual-luciferase reporter analyses revealed that expression levels of all the RA-specific genes and $R A R E$-dependent transcription of luciferase were dramatically elevated in Casp 8 KD ES cells treated with $1 \mu \mathrm{M}$ RA (Figures 2A,B). The enhancement of RA-specific genes expression in Casp8 KD ES cells was significantly induced by even $10 \mathrm{nM}$ RA (Figure 2 - figure supplement 1A). Thus, caspase-8 was shown to suppress evident activation of RA signaling in ES cells. While one of the RA-induced genes, which expression were enhanced by KD of Casp8, was Rarb (RA receptor $\beta$ ), the expression levels of other types of RARs than Rarb, such as Rara, Rarg and Rxra (Zelent et al., 1989; Mattei et al., 1991), were not influenced by KD of Casp8 (Figure 2 - figure supplement 1B). Thus, caspase- 8 suppresses evident activation of RA signaling in ES cells and mechanisms other than a general increase of $R A R S$ expression might be involved in the enhancement of RA signaling in the absence of Casp8 expression. 


\section{Figure 2}

A

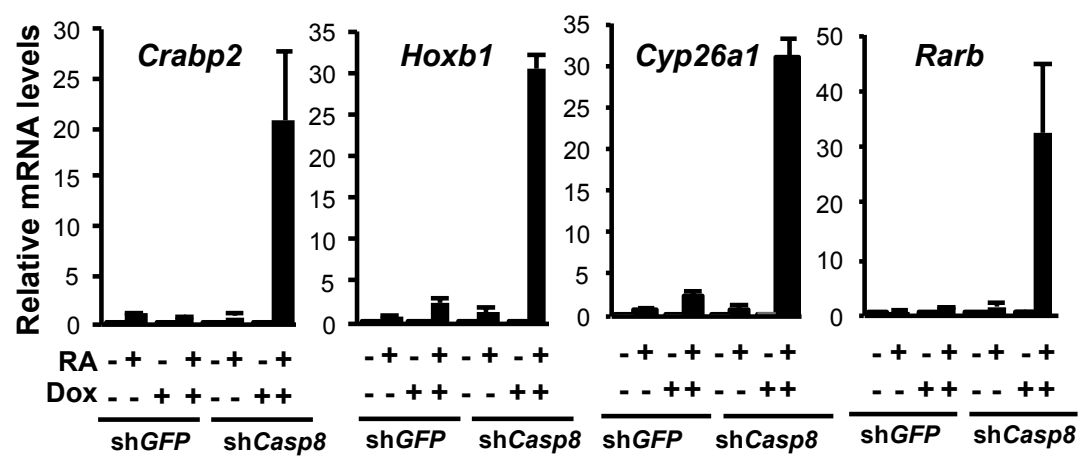

B

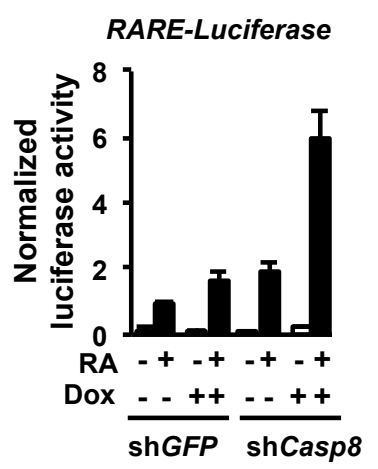

C

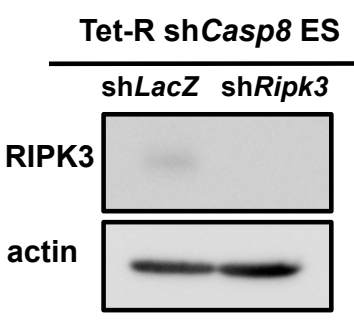

$\mathbf{E}$

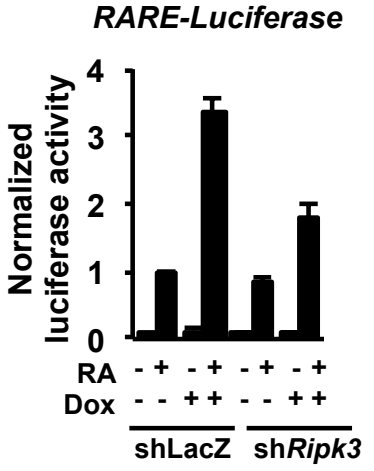

D

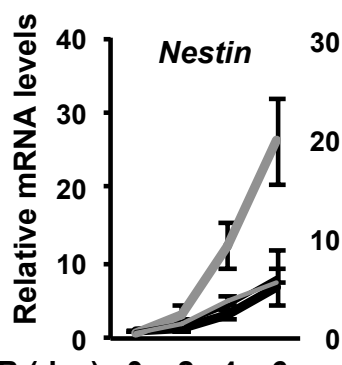

EB (day) $0 \begin{array}{llll}0 & 2 & 4 & 6\end{array}$

$\mathbf{F}$

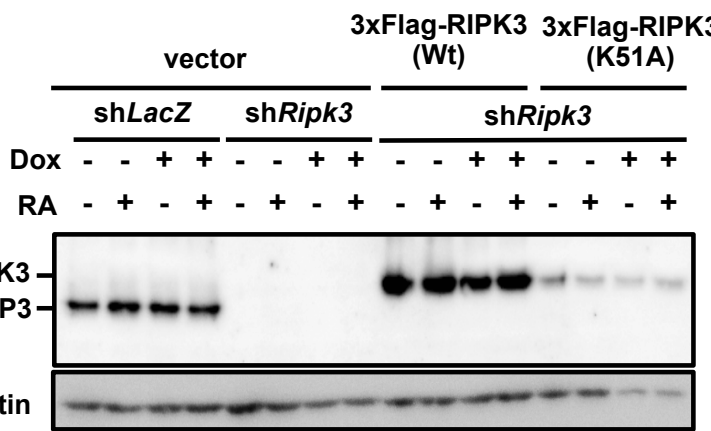

G

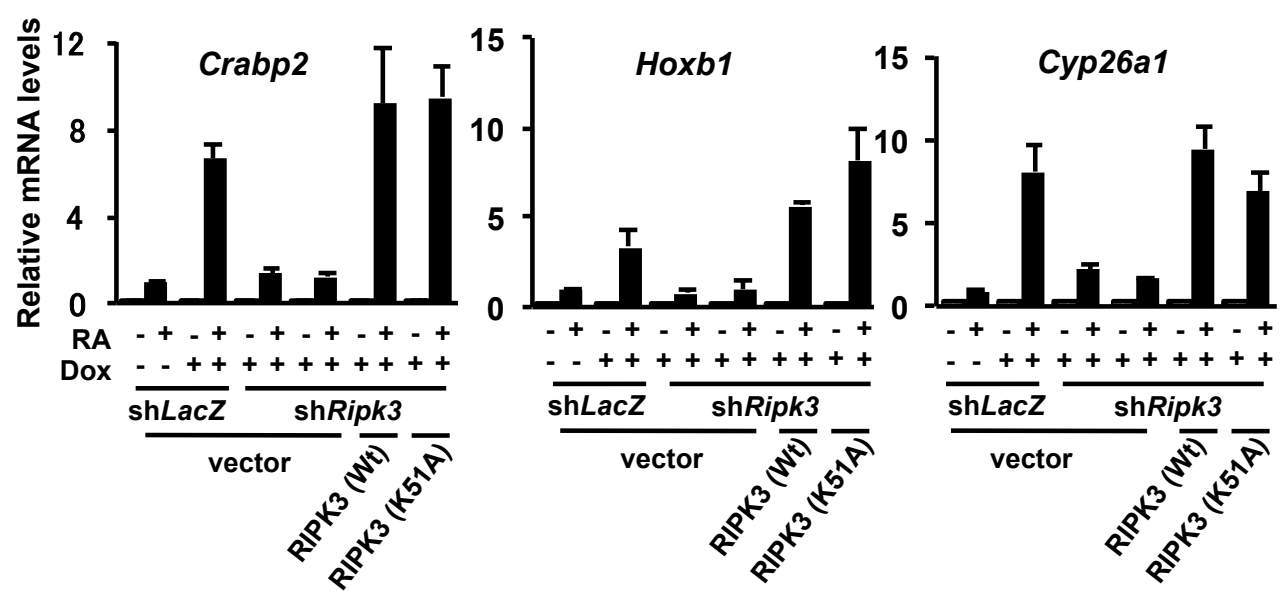




\section{Figure 2 with 5 supplements}

\section{Knockdown of Casp8 expression in ES cells markedly enhances RA signaling dependently on RIPK3.}

(A) Tet-On shCasp 8 and Tet-On shGFP ES cells were cultured for 4 days with or without 1 $\mu \mathrm{g} / \mathrm{ml}$ Dox and then treated with or without $1 \mu \mathrm{M}$ RA for $24 \mathrm{~h}$ in the presence or absence of Dox. Subsequently, expression levels of RA-inducible genes, Crabp2, Hoxb1, Cyp26a1 and Rarb, were analyzed by qRT-PCR. Representative data are shown as means \pm SEM ( $\mathrm{n}=3)$.

(B) Dual-luciferase assay for RARE was performed using Tet-On shCasp 8 or Tet-On shGFP ES cells after treatment with or without $1 \mu \mathrm{M}$ RA for $24 \mathrm{~h}$ in the presence or absence of 1 $\mu \mathrm{g} / \mathrm{ml}$ Dox. Representative data are shown as means $\pm \operatorname{SEM}(\mathrm{n}=3)$.

(C) Western blot analysis of RIPK3 expression was carried out in Tet-On shCasp 8 ES cells expressing $\operatorname{sh} L a c Z$ or shRipk3. Actin was detected as a control.

(D) qRT-PCR analysis of Nestin and Tuj1 expression was performed using EBs derived from

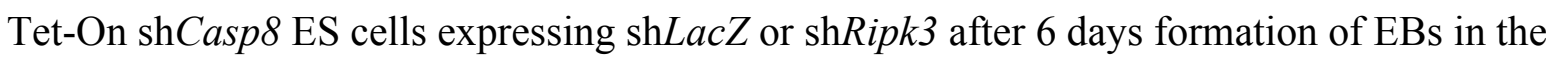
presence or absence of $1 \mu \mathrm{g} / \mathrm{ml}$ Dox. EBs were treated with or without $1 \mu \mathrm{M}$ RA for last 4 days. Representative data are shown as means $\pm \operatorname{SEM}(n=3)$.

(E) Dual-luciferase assay for RARE was carried out using Tet-On shCasp 8 ES cells expressing $\operatorname{sh} L a c Z$ or $\operatorname{sh} R i p k 3$ after treatment with or without $1 \mu \mathrm{M}$ RA for $24 \mathrm{~h}$ in the presence or absence of $1 \mu \mathrm{g} / \mathrm{ml}$ Dox. Representative data are shown as means $\pm \operatorname{SEM}(\mathrm{n}=3)$.

(F and G) Tet-On shCasp8 P19 cells expressing shLacZ or shRipk3 were infected with lentiviral vectors carrying 3xFlag-Wt Ripk3 or K51A Ripk3. These cells were cultured with or without $1 \mu \mathrm{g} / \mathrm{ml}$ Dox for 5 days, and then treated with or without $1 \mu \mathrm{M}$ RA for $24 \mathrm{~h}$ in the presence or absence of Dox. Subsequently, western blot analysis for RIPK3 (F) and qRT-PCR analysis for RA-inducible genes $(\mathrm{G})$ were carried out. vector, an empty vector. Representative data are shown as means $\pm \operatorname{SEM}(n=3)$. 


\section{A}
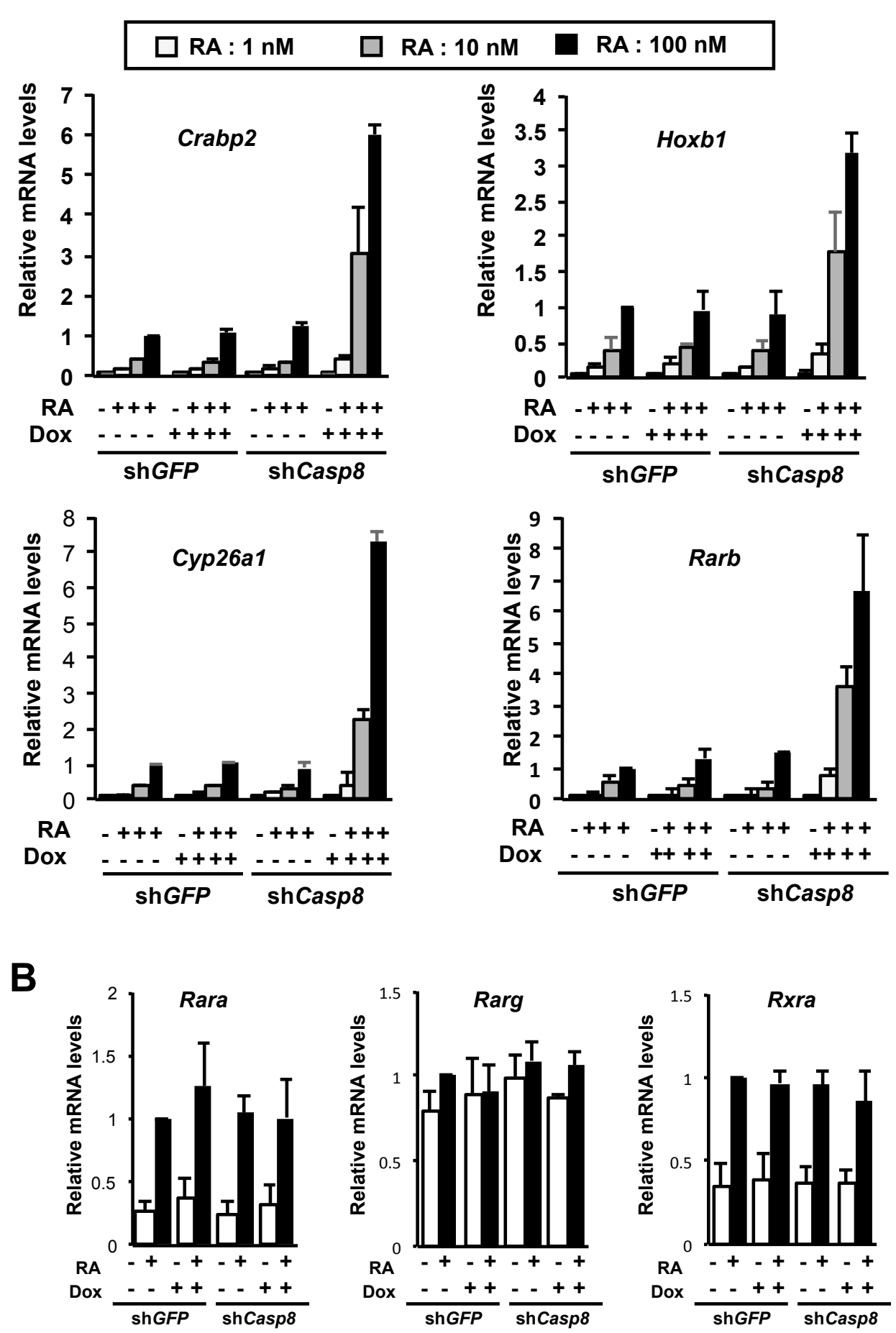

Figure 2 - figure supplement 1

RA signaling in Casp8 KD ES cells.

(A) Tet-On shCasp8 and Tet-On shGFP ES cells were cultured for 4 days with or without $1 \mu \mathrm{g} / \mathrm{ml}$ Dox and then treated with or without $1 \mathrm{nM}, 10 \mathrm{n} \mathrm{M}, 100 \mathrm{nM}$ or $1 \mu \mathrm{M} \mathrm{RA}$ for $24 \mathrm{~h}$ in the presence or absence of Dox. Subsequently, expression levels of RA-inducible genes, Crabp2, Hoxb1, Cyp26a1 and Rarb, were analyzed by qRT-PCR. Representative data are shown as means \pm SEM ( $\mathrm{n}=3)$.

(B) qRT-PCR analysis of RA receptors, Rara, Rarc and Rxra, was carried out using Tet-On shCasp8 and Tet-On shGFP ES cells after treatment with or without $1 \mu \mathrm{M}$ RA for $24 \mathrm{~h}$ in the presence or absence of $1 \mu \mathrm{g} / \mathrm{ml}$ Dox. Representative data are shown as means $\pm \operatorname{SEM}(\mathrm{n}=3)$. 
bioRxiv preprint doi: https://doi.org/10.1101/156901; this version posted June 28, 2017. The copyright holder for this preprint (which was

not certified by peer review) is the author/funder, who has granted bioRxiv a license to display the preprint in perpetuity. It is made available under aCC-BY 4.0 International license.

Someda M et al.

The enhancement of RA signaling as well as RA-induced cell differentiation in the absence of Casp8 expression was observed in not only mouse ES cells but also mouse embryonic carcinoma cell line P19 (Figure 2 - figure supplement 2). In addition, KD of caspase-8 expression in human RA-sensitive cancer cell lines, SK-N-SH and HL60, clearly enhanced RA signaling and RA-induced differentiation into neural cells expressing TUJ1 and monocytes expressing $C D 11 b$, respectively (Figure 2 - figure supplement 3 ). Thus, caspase- 8 suppresses marked activation of RA signaling in not only mouse ES cells but also mouse embryonic carcinoma cells and human cancer cells.

To find out whether the protease activity and/or cleavage-associated activation of caspase- 8 are necessary for inhibition of the evident activation of RA signaling, rescue experiments were carried out using exogenous expression of KD-resistant wild-type (Wt) or two kinds of Casp8 mutants, CS and DE, which hold a Cys to Ser mutation in the protease domain (C362S) and 7 Asp to Glu mutations in expected cleavage sites of caspase-8 itself and other caspases, respectively (Kikuchi et al., 2012). While expressions of Wt and DE Casp8 significantly inhibited the evident activation of RA signaling by Casp $8 \mathrm{KD}$, DE mutant did not really inhibit the activation of RA signaling in Tet-On shCasp8 P19 cells (Figure 2 figure supplement $4 \mathrm{~A}, \mathrm{~B})$. These results show that protease activity of procaspase- 8 is indispensable but cleavage-associated activation of procaspase- 8 is not necessary for 
bioRxiv preprint doi: https://doi.org/10.1101/156901; this version posted June 28,2017 . The copyright holder for this preprint (which was

not certified by peer review) is the author/funder, who has granted bioRxiv a license to display the preprint in perpetuity. It is made available under aCC-BY 4.0 International license.

Someda $\mathrm{M}$ et al.

inhibition of the marked activation of RA signaling. We then analyzed the KD effect of Fadd, a component of the death-inducing signaling complex (DISC) (Chinnaiyan et al., 1997) and the necrosome (He et al., 2009) using Tet-On shFadd ES cells, indicating that KD of Fadd expression induced evident activation of RA-induced neural differentiation and RA-induced genes expression (Figure 2 - figure supplement 4C,D). Taken together, the protease activity of procaspase-8 and FADD prevent marked activation of RA signaling. 
Someda $\mathrm{M}$ et al.

A

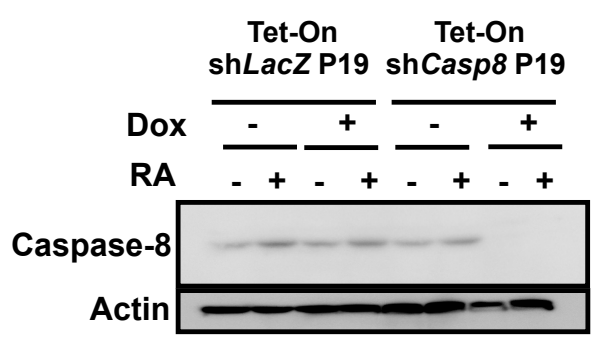

B

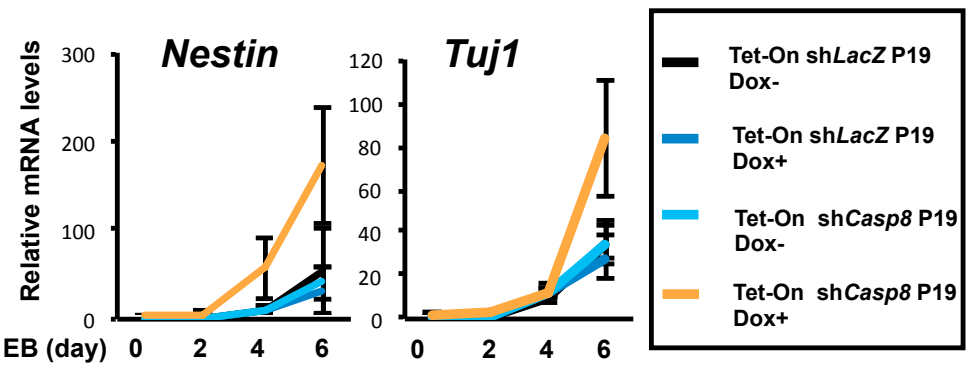

C

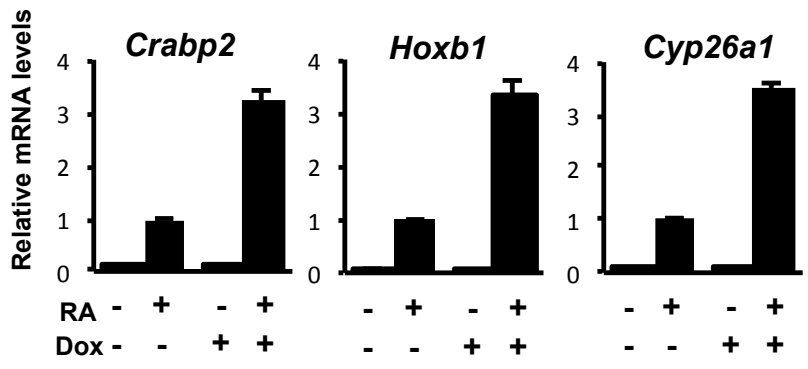

Figure 2 - figure supplement 2

\section{RA-induced differentiation of Casp8 KD P19 cells.}

(A) Tet-On shCasp 8 and Tet-On shLacZ P19 cells were cultured with or without $1 \mu \mathrm{g} / \mathrm{ml}$ Dox for 4 days and then treated with $1 \mu \mathrm{M}$ RA for $24 \mathrm{~h}$ in the presence or absence of Dox. Subsequently, western blot analysis with anti-caspase-8 antibody was performed. Actin was detected as a control. (B) qRT-PCR analysis of Nestin and Tuj1 was carried out using Tet-On shCasp 8 or Tet-On shLacZ P19 cells at the indicated times after formation of EBs in the presence or absence of $1 \mu \mathrm{g} / \mathrm{ml}$ Dox. EBs were cultured with or without $1 \mu \mathrm{M}$ RA after 2 days formation of EBs. Representative data are shown as means \pm SEM $(n=3)$.

(C) qRT-PCR analysis of RA-inducible genes, Crabp2, Hoxb1 and Cyp26a1, was carried out using Tet-On shCasp 8 P19 cells after treatment with or without $1 \mu \mathrm{M}$ RA for $24 \mathrm{~h}$ in the presence or absence of $1 \mu \mathrm{g} / \mathrm{ml}$ Dox. Representative data are shown as means $\pm \operatorname{SEM}(\mathrm{n}=3)$. 
A

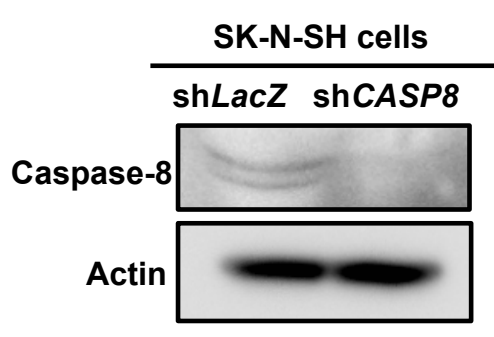

B

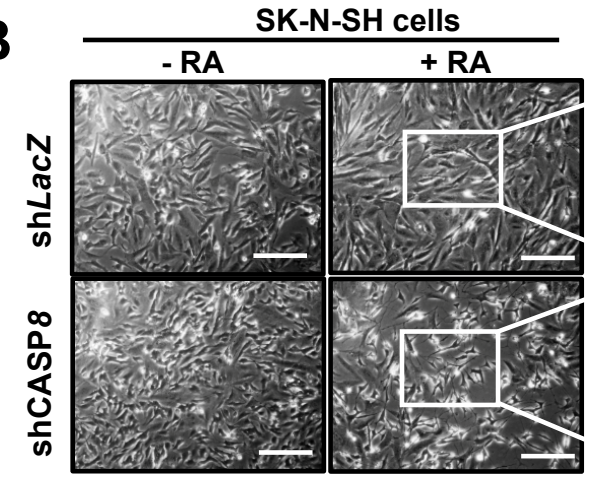

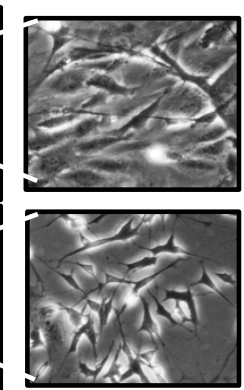

C
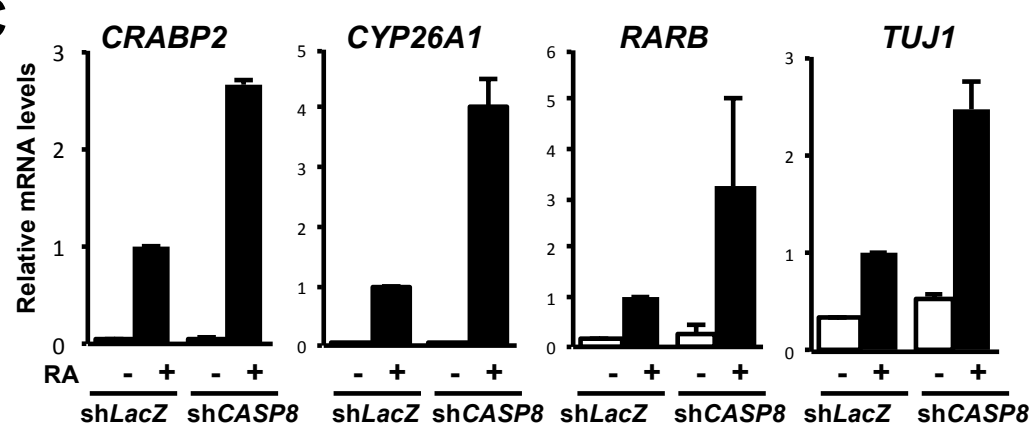

D

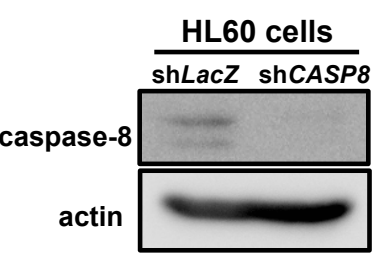

E

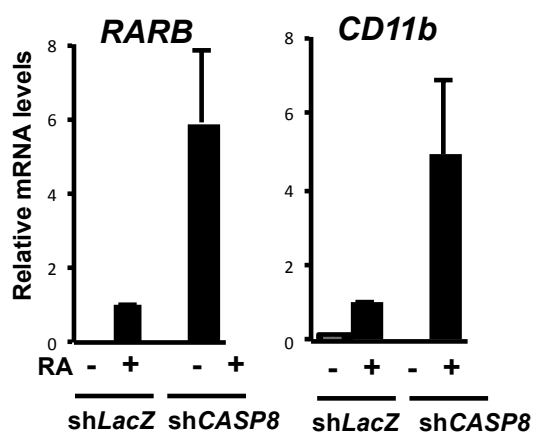

$\mathbf{F}$

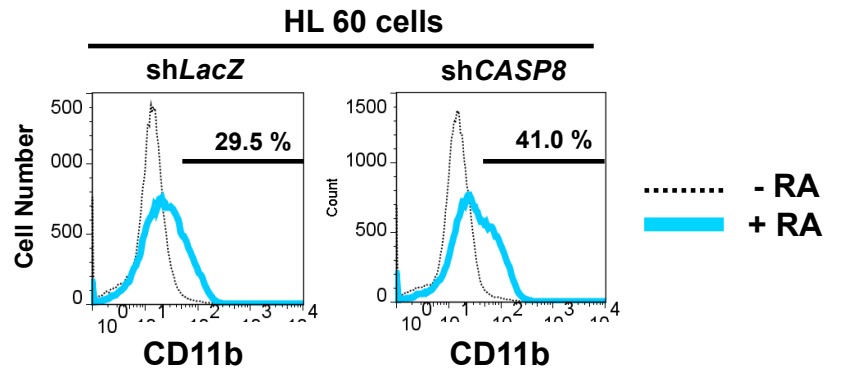

Figure 2 - figure supplement 3

\section{RA-induced differentiation of Casp8 KD SK-N-SH and HL60 cells2.}

(A) Western blot analysis with anti-caspase-8 antibody was carried out using human neuroblastoma-derived SK-N-SH cells expressing shCASP8 or shLacZ. Actin was detected as a control.

(B) Neuronal differentiation of SK-N-SH cells expressing shCASP8 or $\operatorname{sh} L a c Z$ was induced by treatment with $1 \mu \mathrm{M}$ RA for 3 days, and observed by phase-contrast microscopy. Scale bar, 200 $\mu \mathrm{m}$.

(C) qRT-PCR analysis of TUJ1 and RA-induced genes, CRABP2, CYP26A1, and RARB, was carried out using SK-N-SH cells expressing $\operatorname{sh} L a c Z$ or shCASP8 after treatment with or without 1 $\mu \mathrm{M}$ RA for $24 \mathrm{~h}$. Representative data are shown as means \pm SEM ( $\mathrm{n}=3)$.

(D) Human promyelocytic leukemia-derived HL60 cells expressing $\operatorname{sh} L a c Z$ or $\operatorname{sh} C A S P 8$ were monitored for caspase- 8 depletion by western blot analysis with an anti-caspase- 8 antibody. Actin was detected as a control.

(E) qRT-PCR analysis of Rarb and CD11b expression was carried out using HL60 cells expressing shLacZ or shCASP8 before and after treatment with or without $1 \mu \mathrm{M}$ RA for 3 days. Representative data are shown as means \pm SEM $(\mathrm{n}=3)$.

(F) HL60 cells expressing $\operatorname{sh} L a c Z$ or shCASP 8 were treated with or without $1 \mu \mathrm{M}$ RA for 3 days, stained with an FITC-conjugated anti-CD11b antibody and subjected to flow cytometric analysis. 
Someda $\mathrm{M}$ et al.

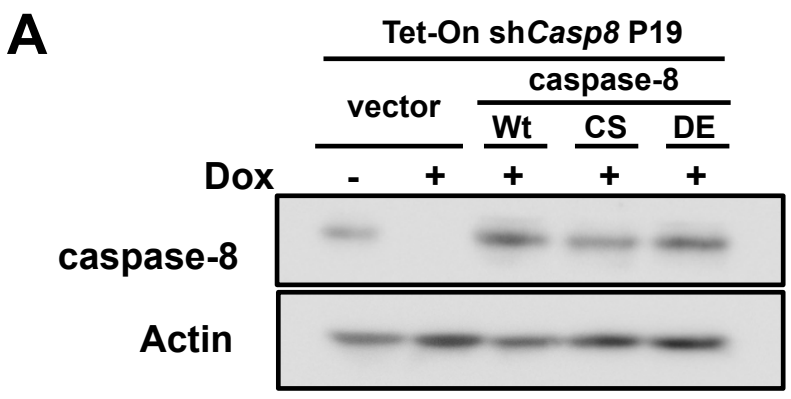

B
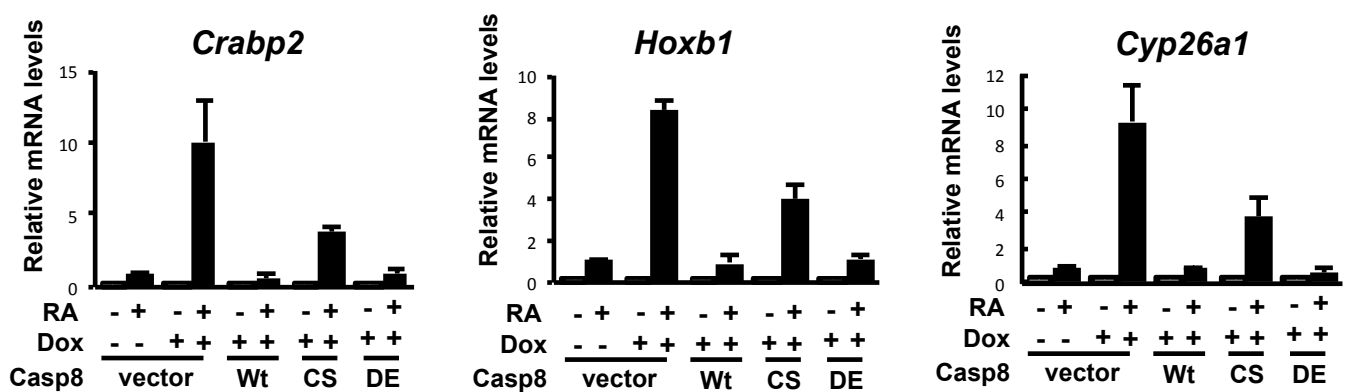

C
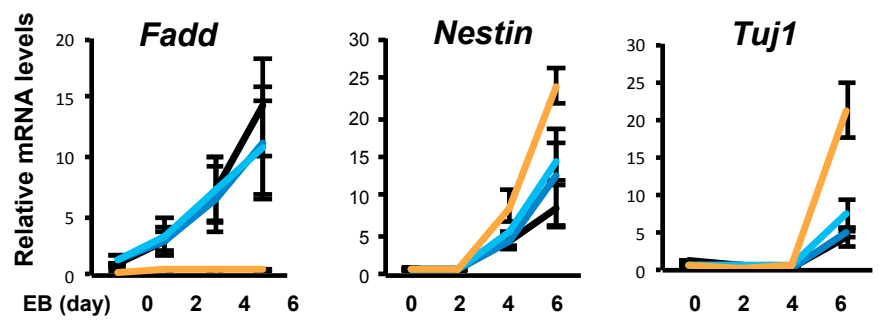

$$
\begin{aligned}
& \text { Tet-On shGFP ES } \\
& \text { Dox- } \\
& \text { Tet-On shGFP ES } \\
& \text { Dox+ } \\
& \text { Tet-On shFadd ES } \\
& \text { Dox- } \\
& \text { Tet-On shFadd ES } \\
& \text { Dox+ }
\end{aligned}
$$
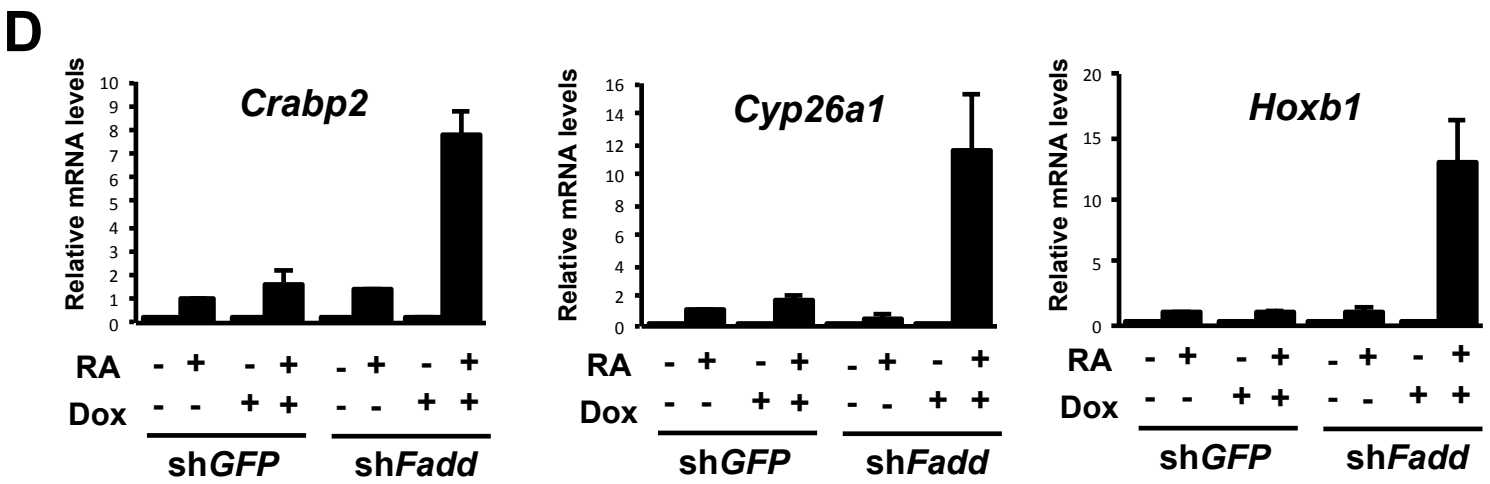
Figure 2 - figure supplement 4

Protease activity of procaspase-8 and FADD regulate the evident activation of RA signaling.

(A) Western blot analysis with an anti-caspase-8 antibody was carried out using Tet-On shCasp8 P19 cells expressing the following Casp 8 cDNA constructs: $\mathrm{Wt}$; a protease-inactive mutant (CS) with a C362S mutation in the protease domain; or a mutant lacking putative cleavage sites (DE) with 7 Asp to Glu mutations in expected cleavage sites of caspase- 8 itself and other caspases (Kikuchi et al. 2012). All the Casp 8 cDNA constructs carried silent mutations in the shCasp 8 target sequence. After treatment with $1 \mathrm{mg} / \mathrm{ml}$ Dox for 4 days, western blot analysis was performed. Actin was detected as a control.

(B) Tet-On shCasp 8 p19 cells were cultured for 4 days with or without $1 \mu \mathrm{g} / \mathrm{ml}$ Dox and then treated with or without $1 \mu \mathrm{M}$ RA for $24 \mathrm{~h}$ in the presence or absence of Dox. Subsequently, expression levels of RA-inducible genes, Crabp2, Hoxb1, and Cyp26al, were analyzed by qRT-PCR. vector, an empty vector. Representative data are shown as means $\pm \operatorname{SEM}(\mathrm{n}=3)$.

(C) qRT-PCR analysis of Fadd, Nestin and Tuj 1 was carried out in Tet-On shGFP and Tet-On shFadd ES cells at the indicated times after formation of EBs in the presence or absence of $1 \mu \mathrm{g} / \mathrm{ml}$ Dox. EBs were cultured with or without $1 \mu \mathrm{M}$ RA after 2 days formation of EBs. Representative data are shown as means \pm SEM $(n=3)$.

(D) Tet-On shFadd and Tet-On shGFP ES cells were cultured for 4 days with or without $1 \mu \mathrm{g} / \mathrm{ml}$ Dox and then treated with or without $1 \mu \mathrm{M}$ RA for $24 \mathrm{~h}$ in the presence or absence of Dox. Subsequently, qRT-PCR analysis of RA-induced genes, Crabp2, Hoxb1 and Cyp26a1, was performed. Representative data are shown as means $\pm \operatorname{SEM}(n=3)$. 


\section{RIPK1 and RIPK3 but MLKL Are Involved in Caspase-8 KD-Induced Enhancement of}

\section{RA Signaling}

Procaspase- 8 and FADD inhibit not only activation of RA signaling but also necroptosis mediated by RIPK1, RIPK3 and MLKL. We then investigated whether these necroptosis-inducing genes were involved in the enhancement of RA signaling. Intriguingly, the marked enhancement of RA-induced differentiation was cancelled by down-regulated expression of Ripk3 using shRipk3 in Casp8 KD ES cells (Figures 2C,D). The enhancement of RA-specific genes expressions and $R A R E$-dependent transcription of luciferase were also cancelled by down-regulating expression of Ripk3 in Casp8 KD P19 cells (Figures 2E-G). In addition, Ripkl was also shown to be involved in the evident enhancement of RA signaling in Casp8 KD ES cells (Figure 2 - figure supplement 5A,B). By contrast, MLKL was not involved in the enhancement of RA signaling in Casp8 KD ES cells (Figure 2 - figure supplement 5C,D). We then asked whether the enhancement of RA signaling was mediated by the kinase activities of RIPK1 and RIPK3, which are required for the induction of necroptosis. In shRipk3-expressing Casp8 KD P19 cells, Casp 8 KD-induced enhancement of RA signaling was restored by exogenous expression of shRNA-resistant cDNAs encoding Wt Ripk3 and a kinase-negative mutant, K51A Ripk3 (Zhang et al., 2009) (Figures 2E,F). Treatment of Casp8 KD P19 cells with a kinase inhibitor of RIPK1, Nec-1 (Degterev et al., 
bioRxiv preprint doi: https://doi.org/10.1101/156901; this version posted June 28,2017 . The copyright holder for this preprint (which was

not certified by peer review) is the author/funder, who has granted bioRxiv a license to display the preprint in perpetuity. It is made available under aCC-BY 4.0 International license.

Someda $\mathrm{M}$ et al.

2005), did not inhibit the Casp 8 KD-induced enhancement of RA signaling (Figure 2 - figure

supplement 5E). These results indicate that both RIPK1 and RIPK3, but not their kinase

activities, play an essential role in the enhancement of RA signaling induced by KD of Casp 8

expression. Collectively, the Casp 8 KD-induced enhancement of RA signaling was shown to

be dependent on RIPK1 and RIPK3 but independent of their necroptosis-inducing activities. 
A

$\mathbf{C}$
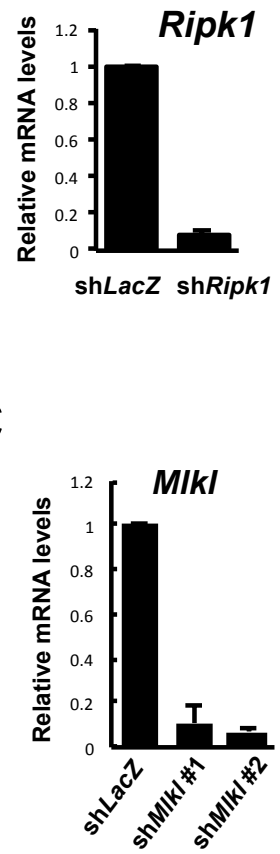

B

E

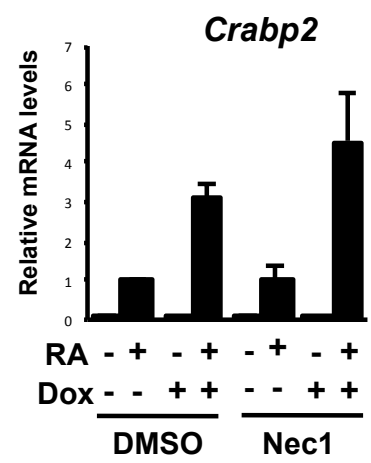

Crabp2

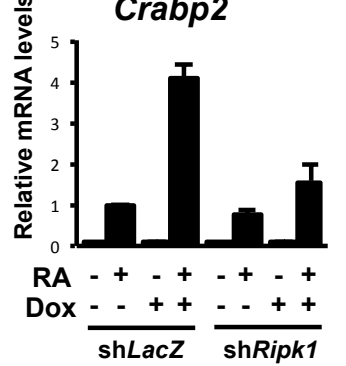

D

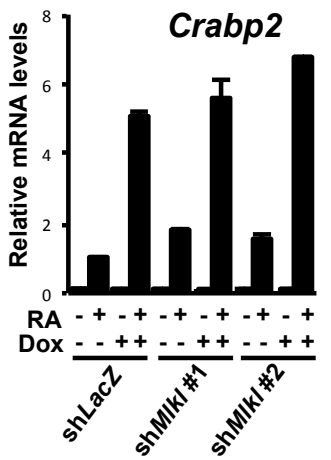

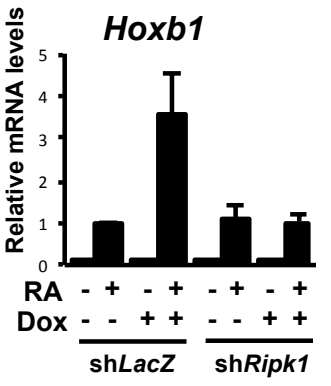
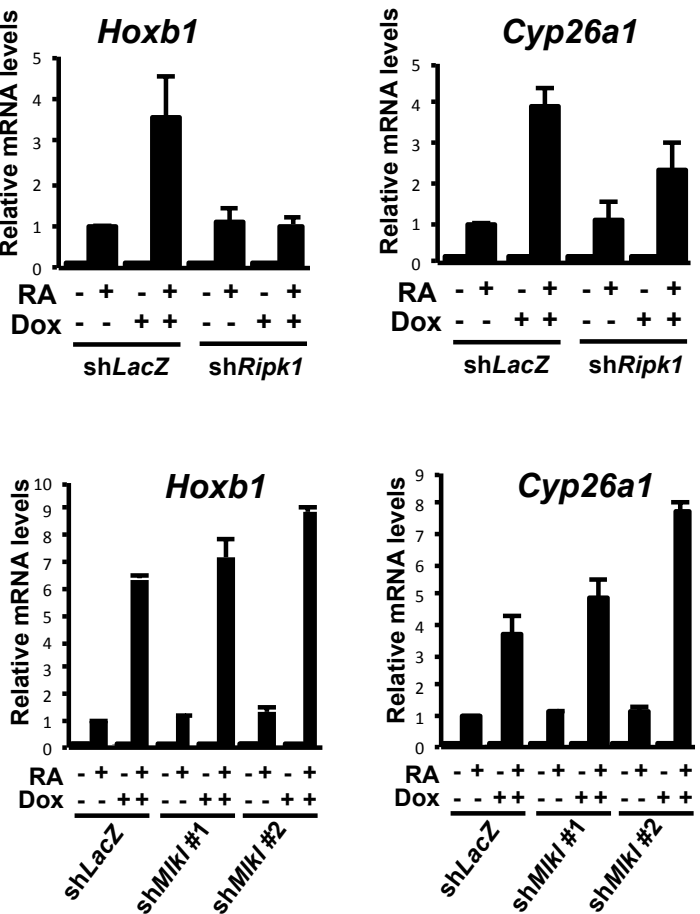

Hoxb1

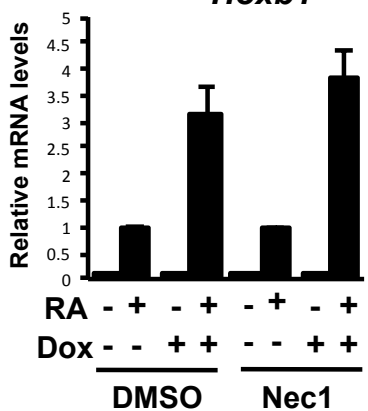

Cyp26a1

Figure 2 - figure supplement 5

RIPK1 but not MLKL is involved in the activation of RA signaling in the absence of Casp8.

(A) Expression levels of Ripk1 were analyzed by qRT-PCR using P19 cells expressing $\operatorname{sh} L a c Z$ or shRipk1. Representative data are shown as means \pm SEM $(n=3)$.

(B) Tet-On shCasp8 P19 cells expressing shLacZ or shRipk1 were cultured for 4 days with or without 1 $\mu \mathrm{g} / \mathrm{ml}$ Dox and then treated with or without $1 \mu \mathrm{M}$ RA for $24 \mathrm{~h}$ in the presence or absence of Dox.

Subsequently, qRT-PCR analysis of RA-induced genes, Crabp2, Hoxb1 and Cyp26a1, was performed. Representative data are shown as means $\pm \operatorname{SEM}(\mathrm{n}=3)$.

(C) Expression levels of $M l k l$ were analyzed by qRT-PCR using P19 cells expressing sh $L a c Z$ or shMlkl. Two shRNAs targeting different nucleotide sequences in $M l k l$ ( $\operatorname{sh} M l k l \# 1$ and shMlkl \#2) were used. Representative data are shown as means $\pm \operatorname{SEM}(n=3)$.

(D) Tet-On shCasp8 P19 cells expressing s shLacZ, shMlkl \#1 or shMlkl \#2 were cultured for 4 days with or without $1 \mu \mathrm{g} / \mathrm{ml}$ Dox and then treated with or without $1 \mu \mathrm{M}$ RA for $24 \mathrm{~h}$ in the presence or absence of Dox.. Subsequently, qRT-PCR analysis of RA-induced genes, Crabp2, Hoxb1 and Cyp26a1, was carried out. Representative data are shown as means $\pm \operatorname{SEM}(n=3)$.

(E) qRT-PCR analysis of RA-induced genes, Crabp2, Hoxb1, and Cyp26a1, was performed using Dox $(1 \mu \mathrm{g} / \mathrm{ml})$-treated or -untreated Tet-On shCasp8 P19 cells cultured with or without $1 \mu \mathrm{M}$ RA for $24 \mathrm{~h}$ in the presence of DMSO or $30 \mu \mathrm{M}$ Nec-1. Representative data are shown as means \pm SEM ( $\mathrm{n}=3$ ). 
bioRxiv preprint doi: https://doi.org/10.1101/156901; this version posted June 28,2017 . The copyright holder for this preprint (which was

not certified by peer review) is the author/funder, who has granted bioRxiv a license to display the preprint in perpetuity. It is made available under aCC-BY 4.0 International license.

Someda $\mathrm{M}$ et al.

\section{Knockdown of Caspase-8 Expression Sensitizes Cells in EBs to RA-Induced Necroptosis}

Two-day RA treatment of EBs derived from Casp 8 KD ES cells were found to be smaller than EBs from Tet-On shCasp8 ES cells treated with Dox but not with RA or those treated with RA but not with Dox (Figures 3A,B). We then analyzed whether cell death was induced in the EBs by LDH release assay, indicating that cell death was clearly and specifically induced in the RA-treated Casp8 KD EBs (Figure 3C). Since caspase-8 was reported to suppress necroptosis mediated by RIPK1, RIPK3 and MLKL (Hitomi et al., 2008; He et al., 2009, Zhang et al., 2009; Wang et al., 2014), we analyzed the effect of necrostatin-1 (Nec-1), a kinase inhibitor for RIPK, on the RA-induced cell death in Casp8 KD EBs. The cell death was inhibited by treatment with Nec-1 (Figures 3A-C), which was shown to be unable to inhibit the marked enhancement of RA signaling in Casp8 KD ES cells (Figure 2 - figure supplement 5E). These results indicated that the mode of death was necroptosis. RA-induced necroptosis in Casp8 KD EBs was inhibited by exogenous expression of Wt Casp8 and CS Casp8 but not by DE Casp8 (Figure 3 - figure supplement 1), indicating that protease activity of procaspase- 8 regulates RA-induced necroptosis as well as RA signaling. Moreover, KD of Ripk3 expression, which could inhibit both necroptosis and the marked enhancement of RA signaling, strongly inhibited RA-induced necroptosis in Casp8 KD ES cells (Figure 3C). To summarize thus far, induced KD of Casp 8 expression in EBs derived form TetR-shCasp $8 \mathrm{ES}$ 
bioRxiv preprint doi: https://doi.org/10.1101/156901; this version posted June 28,2017 . The copyright holder for this preprint (which was

not certified by peer review) is the author/funder, who has granted bioRxiv a license to display the preprint in perpetuity. It is made available under aCC-BY 4.0 International license.

Someda $\mathrm{M}$ et al.

cells markedly and simultaneously sensitized them to RA-induced cell differentiation and necroptosis.

To investigate the mechanism of RA-induced necroptosis in Casp8 KD EBs, expression levels of Ripk1, Ripk3 and Mlkl were quantified in EBs derived from Casp 8 KD ES cells in the presence or absence of RA. During RA-induced differentiation, expression levels of Ripkl, Ripk3 and Mlkl in control ES cells were slightly increased, but their RA-induced expression levels were remarkably up-regulated by KD of Casp8 expression in both mRNA and protein levels (Figures 3D,E). In addition, tumor necrosis factor (TNF), which induces necroptosis in various types of cells, enhanced necroptosis in RA-treated Casp $8 \mathrm{KD}$ EBs, but not in RA-untreated Casp 8 KD EBs (Figure 3F). Thus, the enhancement of RA signaling by Casp 8 KD should sensitize Casp 8 KD cells in EBs to necroptosis induced by TNF through the up-regulation of Ripk1, Ripk3 and Mlkl expression. 
Figure 3

A

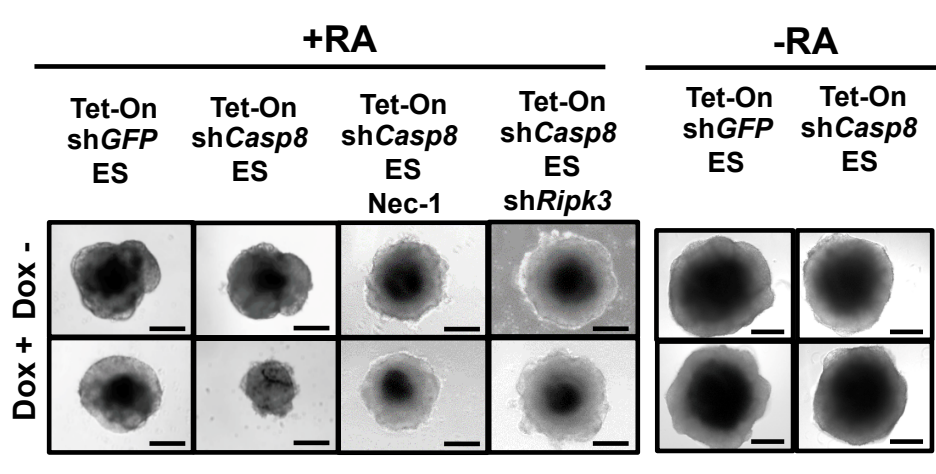

B

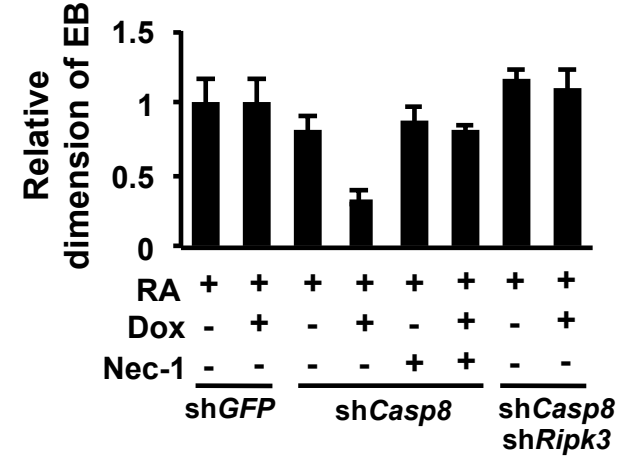

C

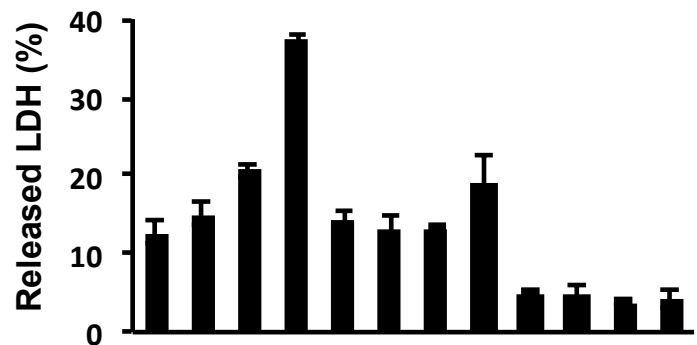

RA - + - + - + - + - + - +

Dox - - + + - - + + - - + +

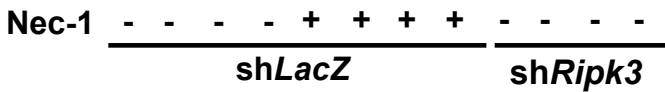

$\mathbf{E}$

Tet-On shGFP ES Tet-On shCasp8 ES

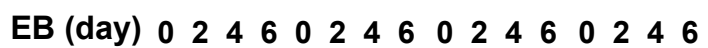

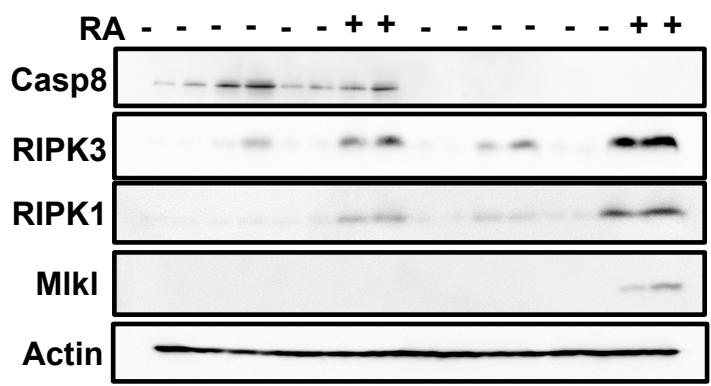

D
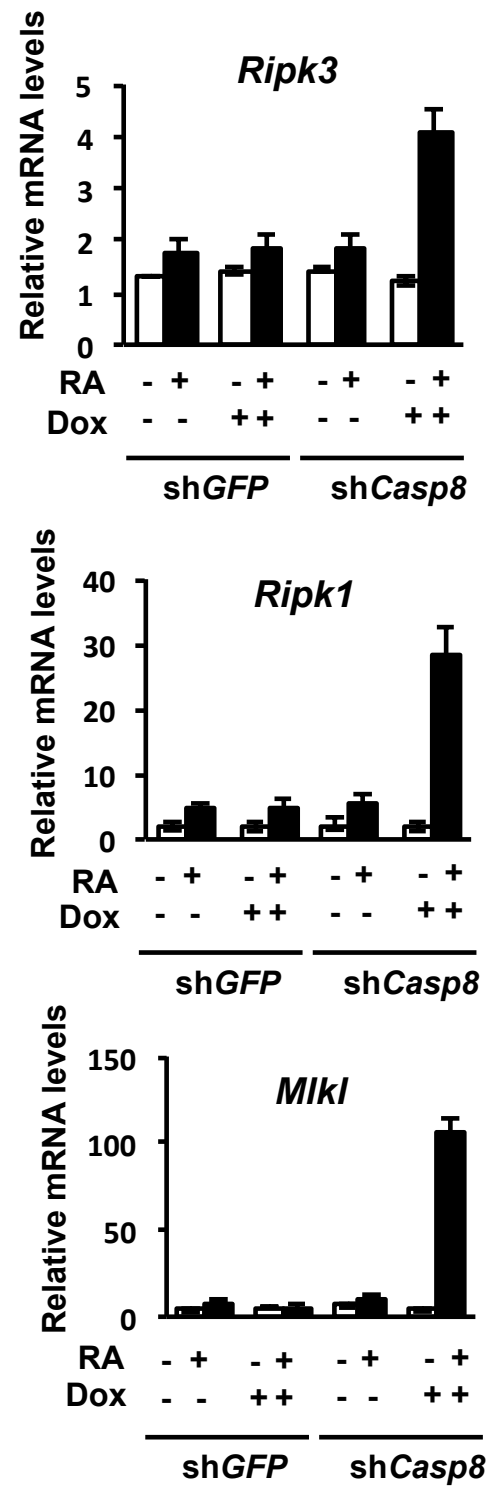

$\mathbf{F}$

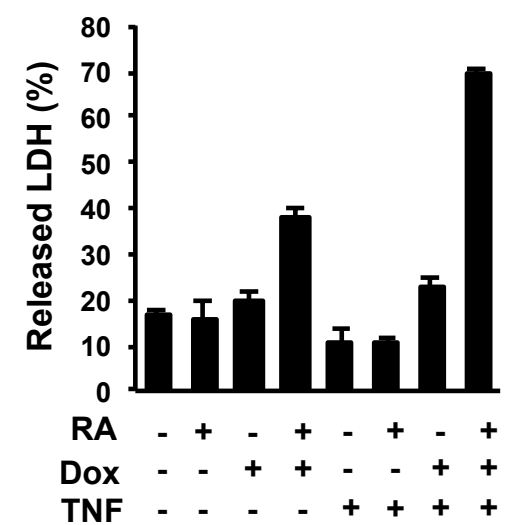




\section{Figure 3 with 1 supplement}

\section{Knockdown of Casp8 in ES cells enhances RA-induced necroptosis.}

(A) Dox $(1 \mu \mathrm{g} / \mathrm{ml})$-treated or -untreated Tet-On shCasp 8 or Tet-On shGFP ES cells with or without expression of shRipk3 were analyzed by phase-contrast microscopy after 4 days formation of EBs. EBs were treated with or without $1 \mu \mathrm{M}$ RA and $30 \mu \mathrm{M} \mathrm{Nec}-1$ for last 2 days. Scale bar, $200 \mu \mathrm{m}$.

(B) Relative diameters of EBs generated as described in (A) were quantified. Representative data are shown as means $\pm \operatorname{SEM}(n=10)$.

(C) Cell death was quantified by a lactate dehydrogenase (LDH) release assay after 4 days of formation of EBs derived from Tet-On shGFP ES cells or Tet-On shCasp8 ES cells with or without expression of shRipk3. EBs were treated with or without $1 \mu \mathrm{M}$ RA and $30 \mu \mathrm{M}$ Nec-1 for last 2 days. Representative data are shown as means $\pm \operatorname{SEM}(n=3)$.

(D) qRT-PCR analysis of Ripk1, Ripk3 and Mlkl were performed using Tet-On shGFP and Tet-On shCasp8 ES cells after 6 days formation of EBs in the presence or absence of $1 \mu \mathrm{g} / \mathrm{ml}$ Dox. EBs were cultured with or without $1 \mu \mathrm{M}$ RA for last 4 days. Representative data are shown as means $\pm \operatorname{SEM}(\mathrm{n}=3)$.

(E) Western blot analysis of Casp8, Ripk1, Ripk3 and Mlkl were performed using Tet-On shGFP and Tet-On shCasp8 ES cells at the indicated times after formation of EBs in the presence or absence of $1 \mu \mathrm{g} / \mathrm{ml}$ Dox. EBs were cultured with or without $1 \mu \mathrm{M}$ RA after 2 days formation of EBs. Actin was detected as a control. 

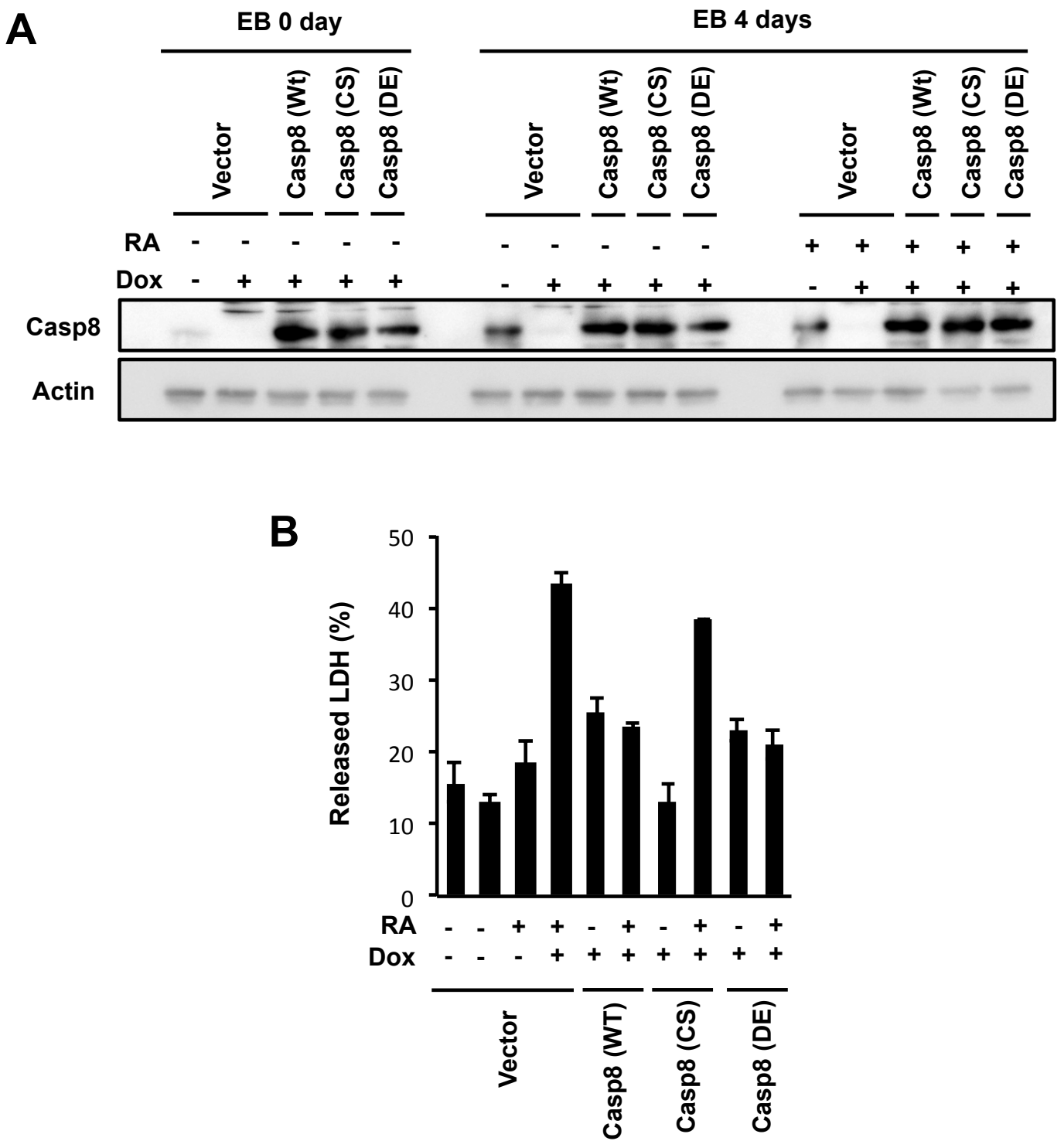

Figure 3- figure supplement 1

Protease activity of procaspase-8 regulates the RA-induced necroptosis, related to Figure 3.

(A) Western blot analysis with an anti-caspase- 8 antibody was performed using Tet-On shCasp 8 ES cells expressing Wt, CS and DE Casp 8 cDNA constructs at the indicated times after formation of EBs in the presence or absence of $1 \mathrm{mg} / \mathrm{ml}$ Dox. EBs were cultured with or without $1 \mu \mathrm{M}$ RA after 2 days formation of EBs. Actin was detected as a control.

(B) Cell death was quantified by an LDH release assay after 4 days of formation of EBs derived from Tet-On shCasp 8 ES cells expressing WT, CS and DE Casp 8 cDNA constructs. EBs were treated with or without $1 \mu \mathrm{M}$ RA for last 2 days. Representative data are shown as means $\pm \mathrm{SEM}$ $(n=3)$. 
bioRxiv preprint doi: https://doi.org/10.1101/156901; this version posted June 28, 2017. The copyright holder for this preprint (which was

not certified by peer review) is the author/funder, who has granted bioRxiv a license to display the preprint in perpetuity. It is made available under aCC-BY 4.0 International license.

Someda $\mathrm{M}$ et al.

\section{KD of Caspase-8 Expression Induces Nuclear Translocation of RIPK1 and RIPK3 to}

\section{Form a Complex with RARs}

To explore the molecular mechanism underlying the casoase- $8 \mathrm{KD}$-induced enhancement of RA signaling, we examined the relationship between RIPKs and RA signaling. Since RIPK1 and RIPK 3 are localized in the cytoplasm under normal conditions and RA binds to RARs in the nucleus, we at first analyzed whether RIPK1 and RIPK3 can translocate into the nucleus. Treatment of Casp8-expressing P19 cells with Leptomycin B (LMB), an inhibitor of nuclear export of proteins (Yang et al., 2004), converted subcellular localization of RIPK3 from cytoplasm to both cytoplasm and nucleus (Figure 4A). LMB treatment induced not only nuclear localization of RIPK3 but also promotion of RA signaling in a RIPK3-dependent manner (Figure 4B), suggesting that RIPK3 in the nucleus enhances RA signaling. In addition, KD of Casp8 expression as well as treatment with LMB converted subcellular localization of RIPK3 from cytoplasm to both cytoplasm and nucleus (Figures 4C,D). Taken together, caspase-8 suppresses nuclear localization of RIPK3, and intranuclear RIPK3 may play an important role in the enhanced activation of RA signaling in the absence of caspase- 8 . 


\section{Figure 4}

A
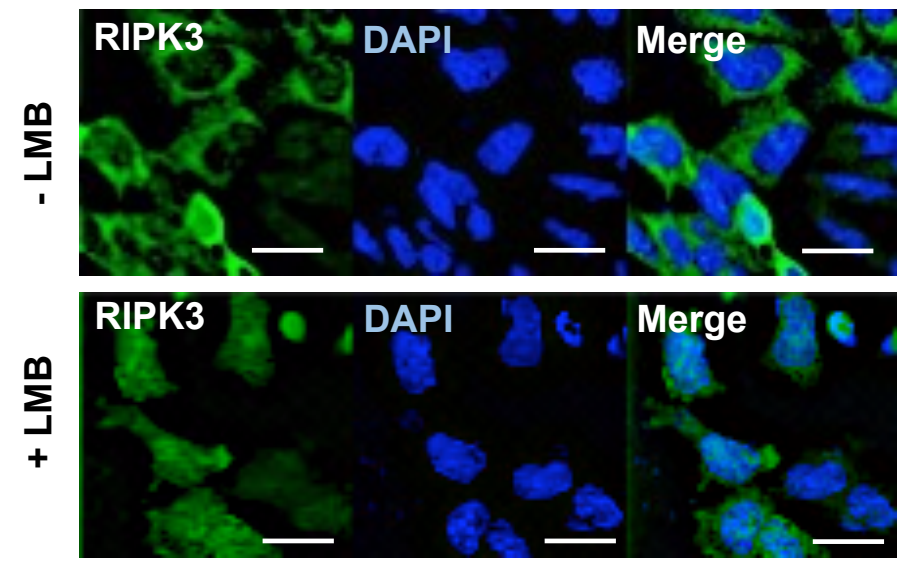

C

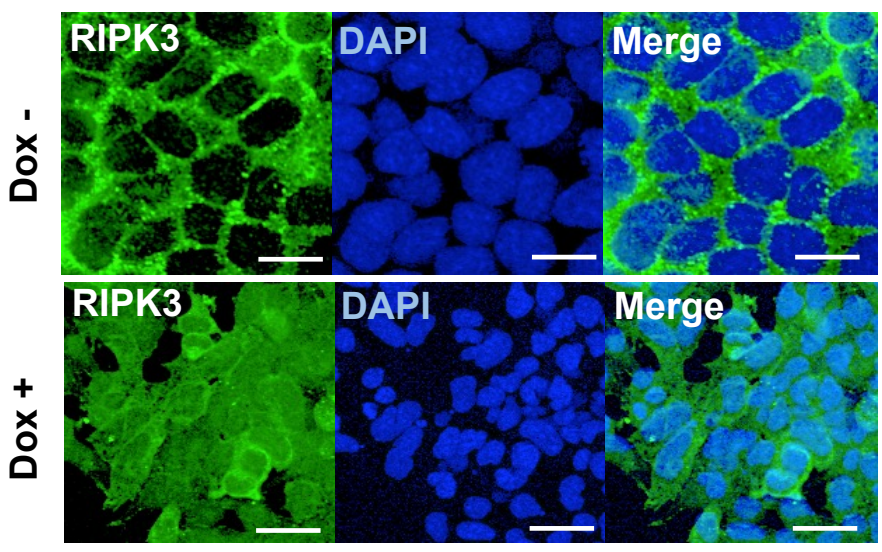

D

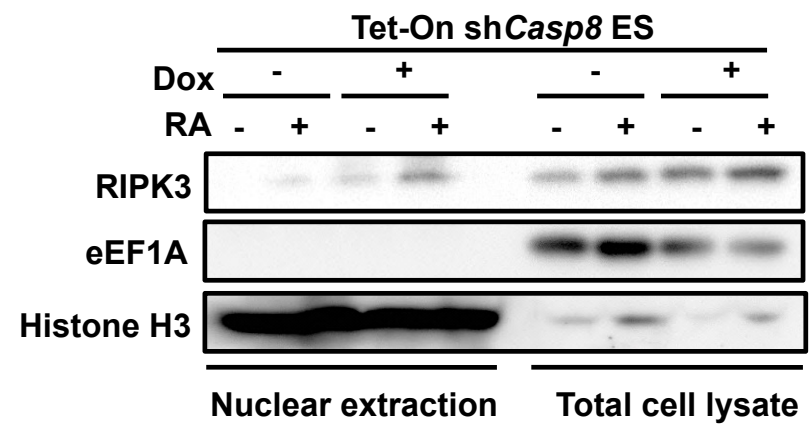

B
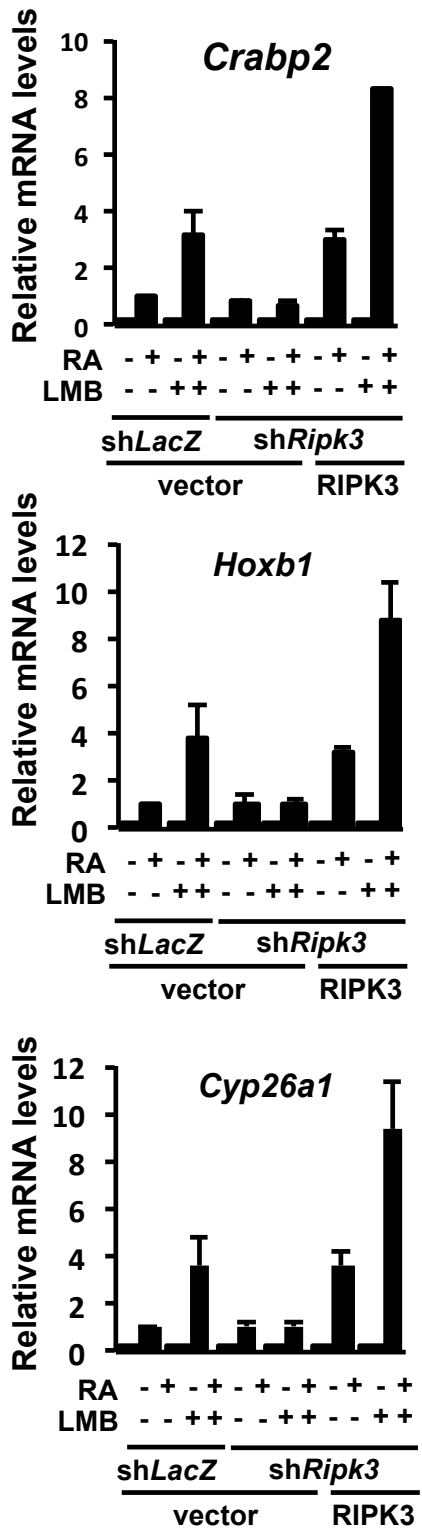


\section{Figure 4}

\section{KD of Casp8 expression induces nuclear translocation of RIPK1 and RIPK3 to enhance}

\section{RA signaling.}

(A) P19 cells expressing shRipk3 and shRipk3-resistant 3xFlag-Ripk3 were treated with or without $1 \mu \mathrm{M}$ RA and $2 \mathrm{ng} / \mathrm{ml} \mathrm{LMB}$ for $24 \mathrm{~h}$, and then subcellular localization of 3xFlag-RIPK3 was analyzed by fluorescence microscopy after staining with DAPI. Scale bar, $20 \mu \mathrm{m}$.

(B) P19 cells expressing shRipk3 and shRipk3-resistant 3xFlag-Ripk3 were subjected to qRT-PCR analysis of RA-induced genes, Crabp2, Hoxb1 and Cyp26a1, after treatment with or without $1 \mu \mathrm{M} \mathrm{RA}$ and $2 \mathrm{ng} / \mathrm{ml} \mathrm{LMB}$ for $24 \mathrm{~h}$. vector, an empty vector. Representative data are shown as means $\pm \operatorname{SEM}(\mathrm{n}=3)$.

(C) Tet-On shCasp8 P19 cells expressing shRipk3 and shRipk3-resistant 3xFlag-Wt Ripk3 were cultured with or without $1 \mu \mathrm{g} / \mathrm{ml}$ Dox for 4 days in the presence or absence of Dox. Subsequently, subcellular localization of 3xFlag-RIPK3 was analyzed by fluorescence microscopy using anti-Flag antibody after staining with DAPI. Scale bar, $20 \mu \mathrm{m}$.

(D) Western blot analysis of endogenous RIPK3 from nuclear fractions and total cell lysates was carried out using Tet-On shCasp 8 ES cells cultured with or without $1 \mu \mathrm{g} / \mathrm{ml}$ Dox for 5 days. Cells were treated with or without $1 \mu \mathrm{M}$ RA for last $24 \mathrm{~h}$. Cytoplasmic eEF1A1 and nuclear Histone H3 were simultaneously analyzed. 
bioRxiv preprint doi: https://doi.org/10.1101/156901; this version posted June 28, 2017. The copyright holder for this preprint (which was

not certified by peer review) is the author/funder, who has granted bioRxiv a license to display the preprint in perpetuity. It is made available under aCC-BY 4.0 International license.

Someda $\mathrm{M}$ et al.

Subcellular localization of exogenously expressed mCherry-RIPK3 in P19 cells was also converted from cytoplasm to both cytoplasm and nucleus by overexpression of RAR $\alpha$, which is a nuclear protein (Figure 5A). Overexpressed RAR $\alpha$ seemed to retain RIPK3 in nucleus. We then analyzed the interaction of RAR $\alpha$ with RIPK1 and RIPK3. In co-immunoprecipitation experiments, exogenously expressed RIPK3 interacted with exogenously expressed RAR $\alpha$ in HEK293T cell extracts (Figure 5B), and immunoprecipitation of exogenous Flag-tagged RIPK3 with anti-Flag antibody co-precipitated endogenous RAR $\alpha$ in Casp8 KD ES cells (Figure 5C). Importantly, endogenous RIPK1 and RIPK3 were co-immunoprecipitated with endogenous RAR $\alpha$ with an anti-RAR antibody from lysates of Casp8 KD ES cells (Figure 5D). Moreover, the interactions of RAR $\alpha$ to both RIPK1 and RIPK3 were shown to be enhanced by treatment with RA. Thus, KD of Casp8 expression induced nuclear localization of RIPK3, and RIPK1 and RIPK3 interacted with RAR $\alpha$ in the nucleus might activate RA signaling. 


\section{Figure 5}

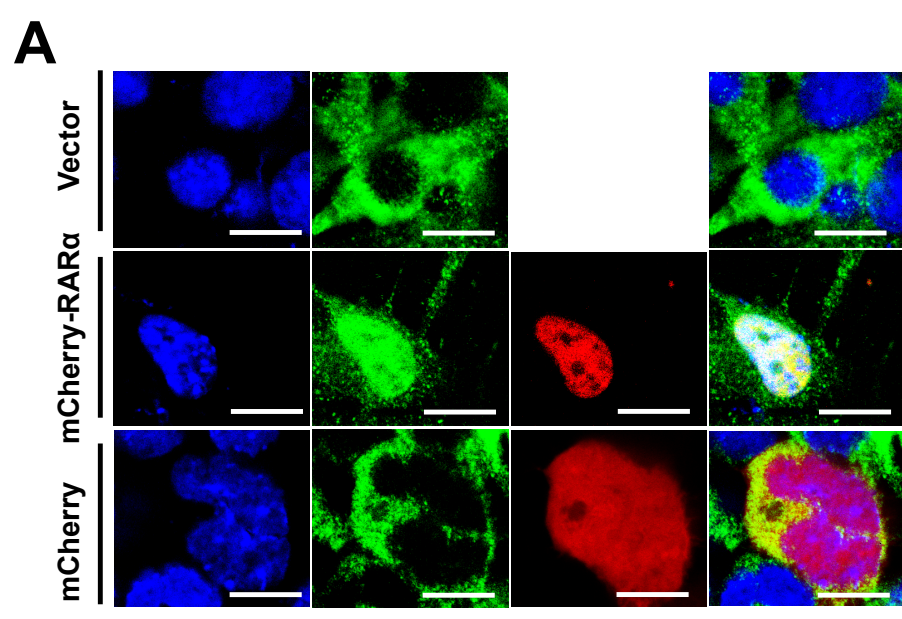

B

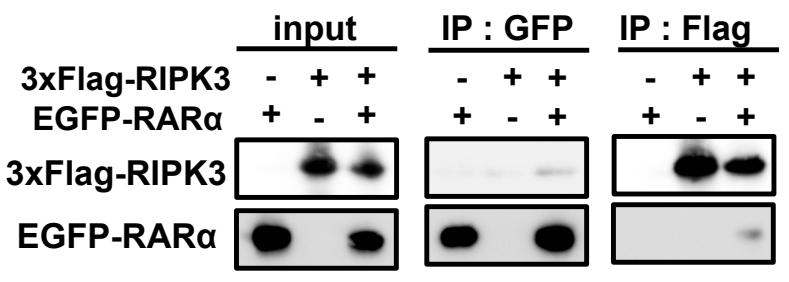

C

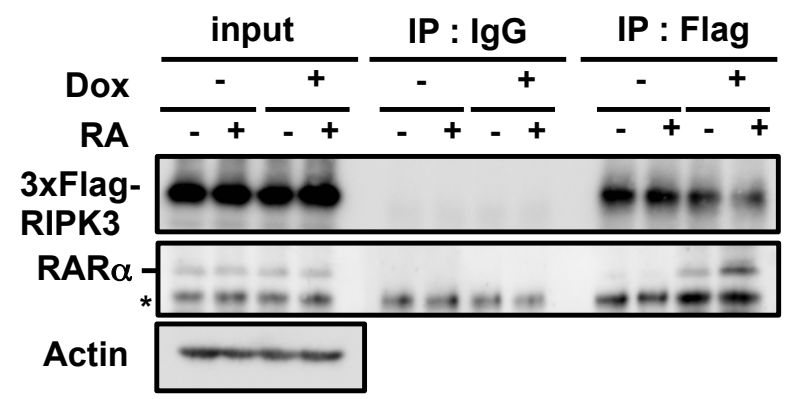

D

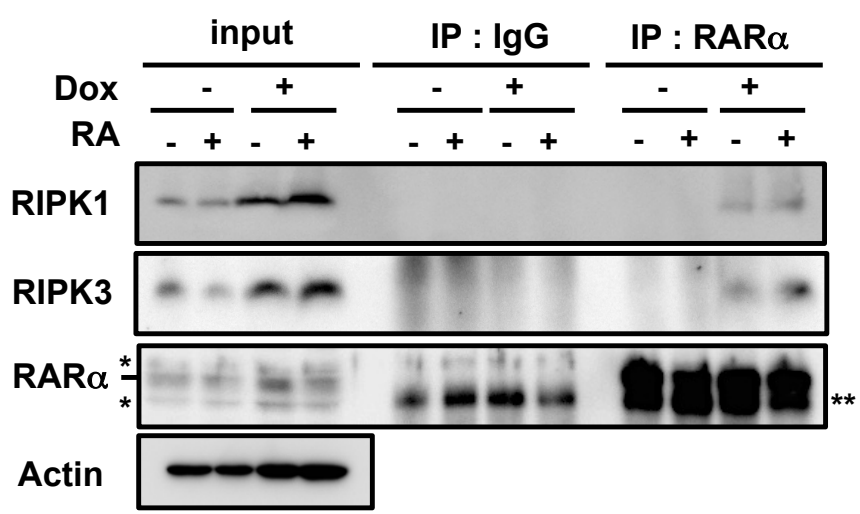




\section{Figure 5 with one supplement}

\section{RIPK1 and RIPK3 interact with RAR $\alpha$.}

(A) P19 cells expressing shRipk3 and shRipk3-resistant 3xFlag-Ripk3 were transfected with an expression vector encoding mCherry-RAR $\alpha$ or mCherry, and cultured for $48 \mathrm{~h}$. Then, subcellular localization of mCherry-RAR $\alpha$ or mCherry was analyzed by fluorescence microscopy after staining with DAPI. Scale bar, $20 \mu \mathrm{m}$.

(B) Lysates of HEC293T cells transiently expressing 3xFlag-tagged RIPK3 and/or EGFP-RAR $\alpha$ were subjected to immunoprecipitation with anti-Flag antibody or anti-GFP antibody, and analyzed by western blotting with anti-Flag antibody or anti-GFP antibody. Total cell lysates (input) were also analyzed.

(C and D) Western blot analysis was carried out for immunoprecipitates (IP) with control IgG and ant-Flag Ab from Tet-On shCasp 8 ES cells expressing 3xFlag-Wt Ripk3 with control IgG or anti-RAR $\alpha$ from Tet-On shCasp 8 ES cells (C), or IP with control IgG or anti-RAR $\alpha$ from Tet-On shCasp8 ES cells (D).). Total cell lysates (Input) were also analyzed. *: nonspecific bands, ** : IgG-derived bands. 
bioRxiv preprint doi: https://doi.org/10.1101/156901; this version posted June 28,2017 . The copyright holder for this preprint (which was

not certified by peer review) is the author/funder, who has granted bioRxiv a license to display the preprint in perpetuity. It is made available under aCC-BY 4.0 International license.

Someda $\mathrm{M}$ et al.

In co-immunoprecipitation experiments, exogenously expressed RIPK3 interacted with exogenously expressed RAR $\alpha$ in HEK293T cell extracts (Figure 5B), and co-immunoprecipitation analyses using various deletion mutants of RAR $\alpha$ and RIPK3 indicated that RIPK3 and RAR $\alpha$ interacted through the ligand-binding domain (LBD) of RAR $\alpha$ and the protein kinase domain (PKD) of RIPK3 (Figure 5 - figure supplement 1). Since RIPK3 was reported to directly bind to RIPK1 through its RHIM domain, RIPK3 would be able to function as an adaptor protein through binding to RIPK1 and RAR $\alpha$ via its RHIM and kinase domains, respectively. 
A

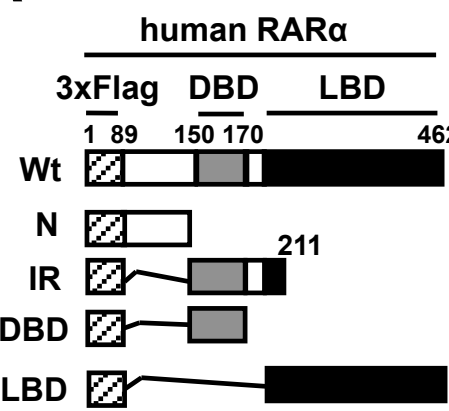

C

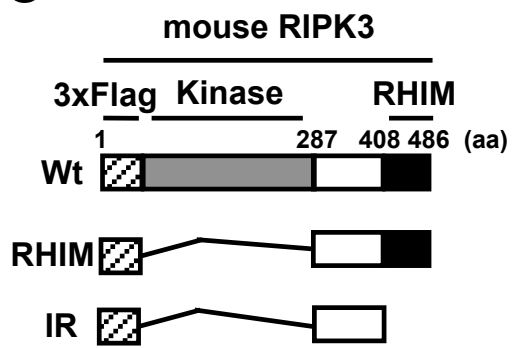

PKD $Q$
B

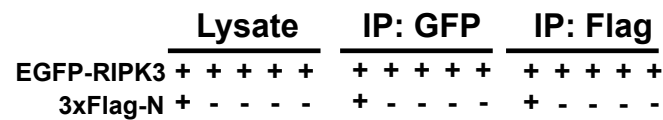

3xFlag-IR - + - - - - + - - - - + - 3xFlag-DBD - - + - - - + + - - + + -

3xFlag-LBD - - - + - - - - + - - - - + 3xFlag-Wt - - - - + - - - - + - - - - +

WB: anti-Flag

WB: anti-GFP

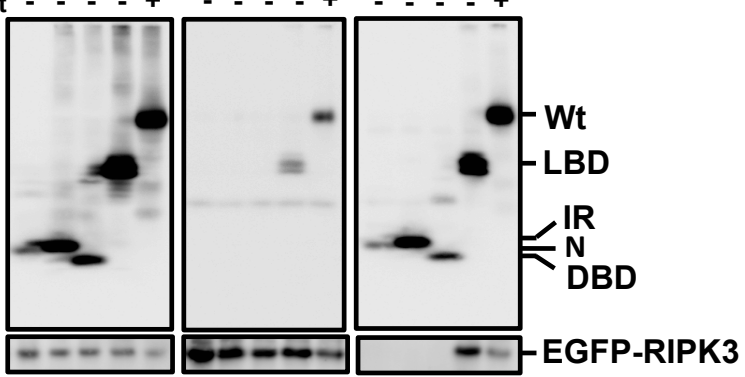

WB: anti-Flag

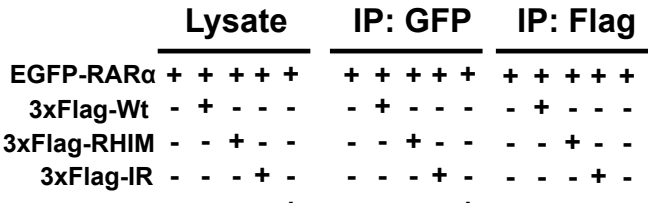

3xFlag-KD - - - + $+-\ldots+\ldots \ldots$

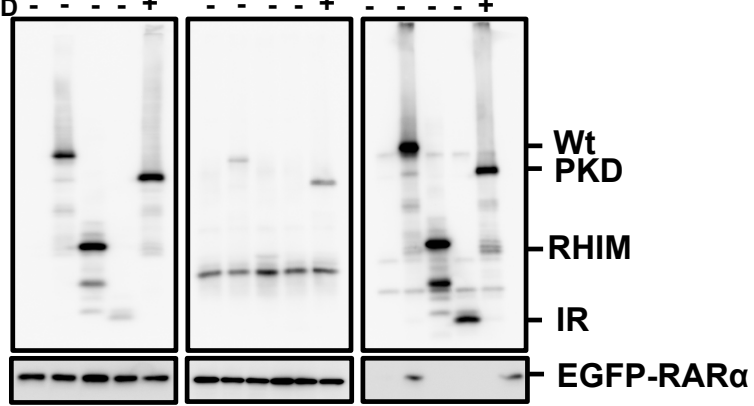

Figure 5 - figure supplement 1

The ligand-binding domain (LBD) of RAR $\alpha$ interacts with the protein kinase domain (PKD) of RIPK3, related to Figure 5

(A) Graphical overview of 3xFlag-tagged full-length human RAR $\alpha(\mathrm{Wt})$ and its various deletion mutants. The numbers of amino acid residues in RAR $\alpha$ are indicated. $\mathrm{N}$, N-terminal domain of RAR $\alpha$; IR, intermediate region of RAR $\alpha$; DBD, DNA-binding domain of RAR $\alpha$; and LBD, ligand binding domain of RAR $\alpha$.

(B) Lysates of HEC293T cells transiently expressing EGFP-RIPK3 and various deletion mutants of $3 x$ Flag-RAR $\alpha$ were subjected to immunoprecipitation with anti-Flag or anti-GFP antibodies, and IP were analyzed by western blotting with anti-Flag or anti-GFP antibodies. Total cell lysates (Lysate) were also analyzed.

(C) A graphical overview of 3xFlag-tagged full-length mouse RIPK3 (Wt) and its various deletion mutants. Relevant numbers of amino acid residues in RIPK3 are indicated. RHIM, RIPK homotypic interaction motif (RHIM) domain; IR, intermediate region; and PKD, protein kinase domain. (D) HEC293T cells transiently expressing EGFP-RAR $\alpha$ or various deletion mutants of 3xFlagRIPK3 were subjected to immunoprecipitation with anti-Flag or anti-GFP antibodies, and analyzed by western blotting with anti-Flag or anti-GFP antibodies. Total cell lysates (Lysate) were also analyzed. 


\section{The Complex of RIPK1, RIPK3 and RARs Works in The Coactivator Complex to}

\section{Enhance RA-Dependent Transcription}

To clarify whether the complex of RIPK1, RIPK3 and RARs functions in RA-dependent transcription, chromatin immunoprecipitation (ChIP) analysis was carried out in Casp8 KD ES cells. RA treatment was indicated to notably enhance binding of endogenous RIPK1 to $R A R E$ of an RA-inducible gene, Rarb, specifically in the absence of Casp 8 expression (Figure 6A). RA treatment also clearly enhanced binding of exogenously expressed Wt and a kinase-negative mutant, K51A RIPK3 to RARE of an RA-inducible gene, Cyp26al, in the absence of endogenous Ripk3 and Casp8 expressions (Figure 6B). Furthermore, KD of Casp8 significantly enhanced RA-induced biding of RARs to RARE dependently on Ripk3 expression but independently on the kinase activity of RIPK3 (Figure 6C). Taken together, RARs, bound to RIPK1 and RIPK3 in the nucleus of Casp 8 KD cells, showed much stronger binding activity to RARE in the presence of RA than RARs without RIPK1 and RIPK3.

Caspase- $8 \mathrm{KD}$-induced enhancement of RA signaling was shown to be dependent upon RXR $\alpha$, TDG, p300 and CBP (Figure 6 - figure supplement 1), all of which were reported to form a transcriptional coactivator complex with RAR on RAREs and to enhance RA signaling (Um et al., 1998; Lee et al., 2009; Cortellino et al., 2011). Collectively, all the results suggest that RIPK1 and RIPK3 form a coactivator complex with RAR/RXR, TDG, p300 and CBP in 
bioRxiv preprint doi: https://doi.org/10.1101/156901; this version posted June 28,2017 . The copyright holder for this preprint (which was

not certified by peer review) is the author/funder, who has granted bioRxiv a license to display the preprint in perpetuity. It is made available under aCC-BY 4.0 International license.

Someda $\mathrm{M}$ et al.

the nucleus of Casp8 KD cells, RA treatment induces tight binding of the

RIPK1/RIPK3-containing coactivator complex onto RAREs, and RA signaling is subsequently

enhanced. 


\section{Figure 6}

A

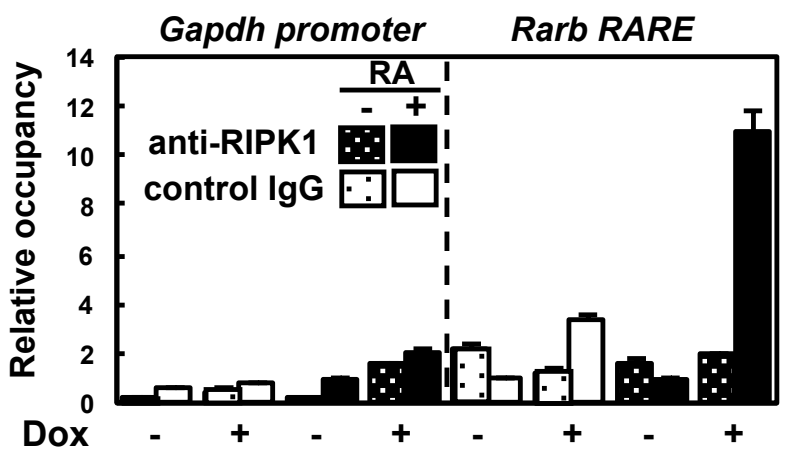

B

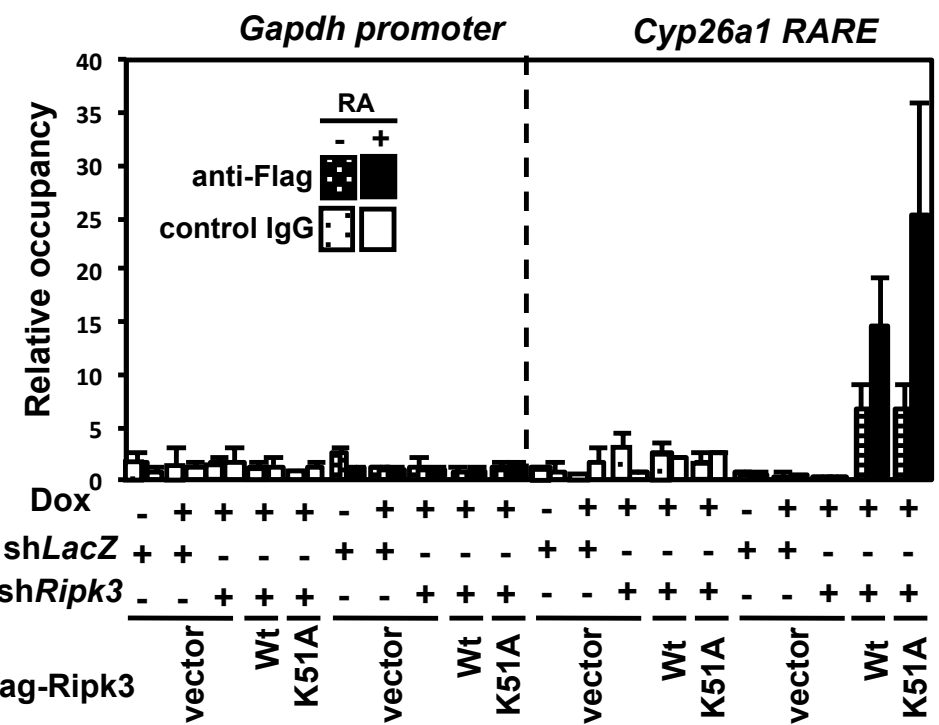

C

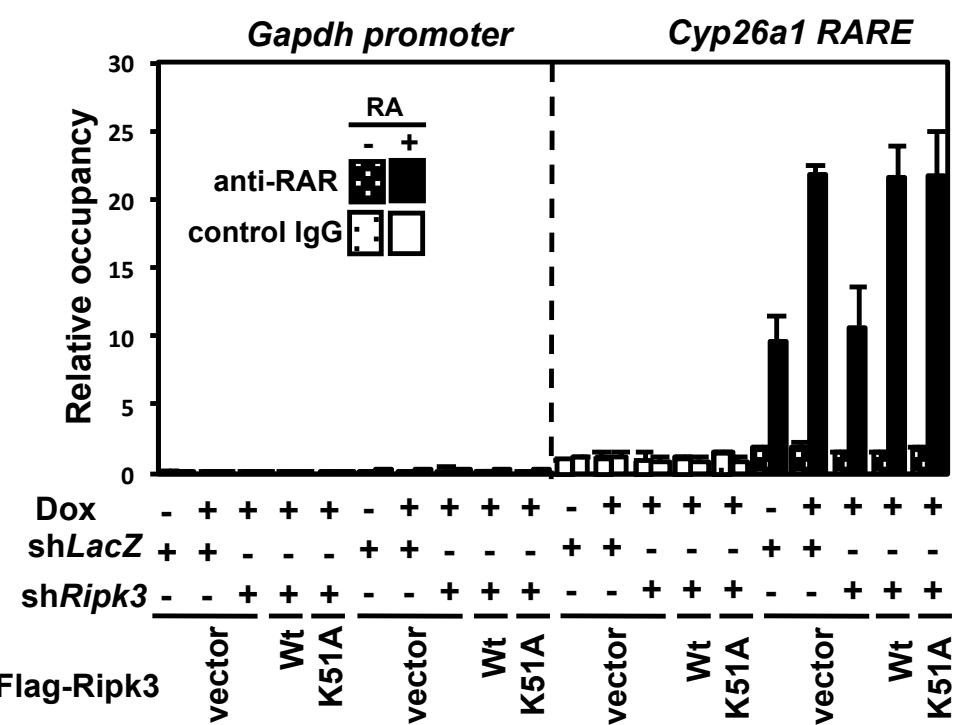




\section{Figure 6 with one supplement}

\section{RA treatment notably enhances binding of not only RARs but also RIPK1 and RIPK3 to}

\section{RAREs of RA-inducible genes in the absence of Casp8 expression.}

(A) Tet-On shCasp8 and shGFP ES cells were cultured with or without $1 \mu \mathrm{g} / \mathrm{ml}$ Dox for 4 days and then treated with or without $1 \mu \mathrm{M}$ RA for $24 \mathrm{~h}$ in the presence or absence of Dox. Subsequently, ChIP analysis for the Rarb-specific $R A R E$ using an anti-RIPK1 antibody was carried out. Representative data are shown as means $\pm \operatorname{SEM}(n=3)$.

(B and C) Tet-On shCasp8 P19 cells expressing shLacZ or shRipk3 together with or without shRipk3-resistant 3xFlag-Wt or K51A Ripk3 (kinase-negative form of RIPK3) were treated with or without $1 \mu \mathrm{M}$ RA for $24 \mathrm{~h}$ in the presence or absence of $1 \mu \mathrm{g} / \mathrm{ml}$ Dox, and subjected to ChIP analysis using anti-Flag antibody or control IgG (B), and anti-RAR antibody or control IgG (C). vector, an empty vector. Representative data are shown as means \pm SEM $(n=3)$. 
Someda $\mathrm{M}$ et al.

A

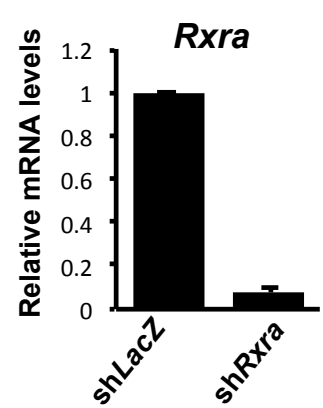

B
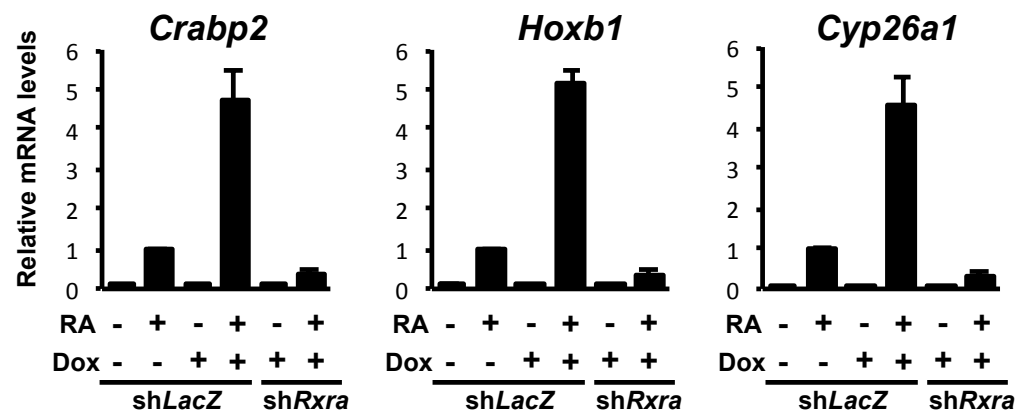

C
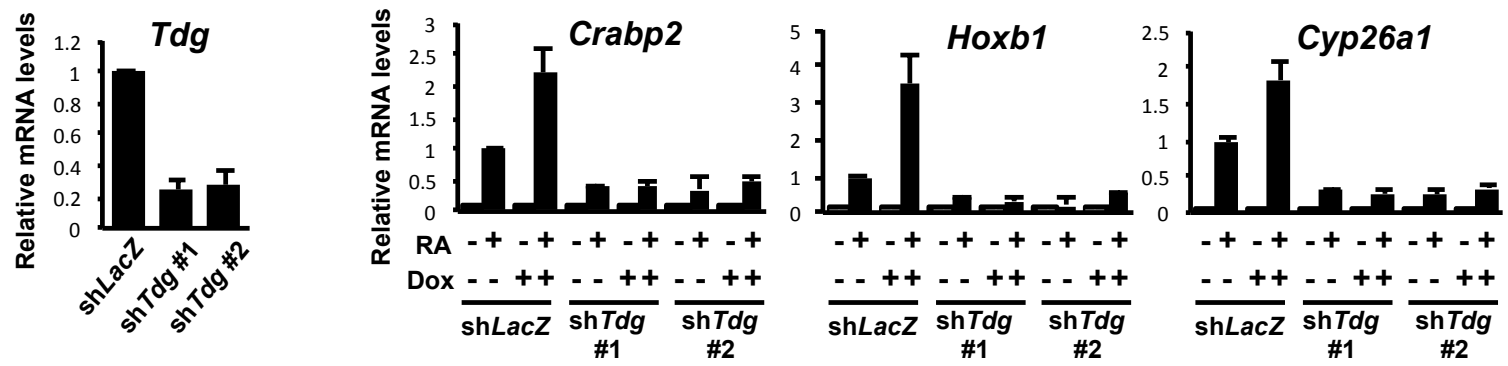

$\mathbf{E}$

F
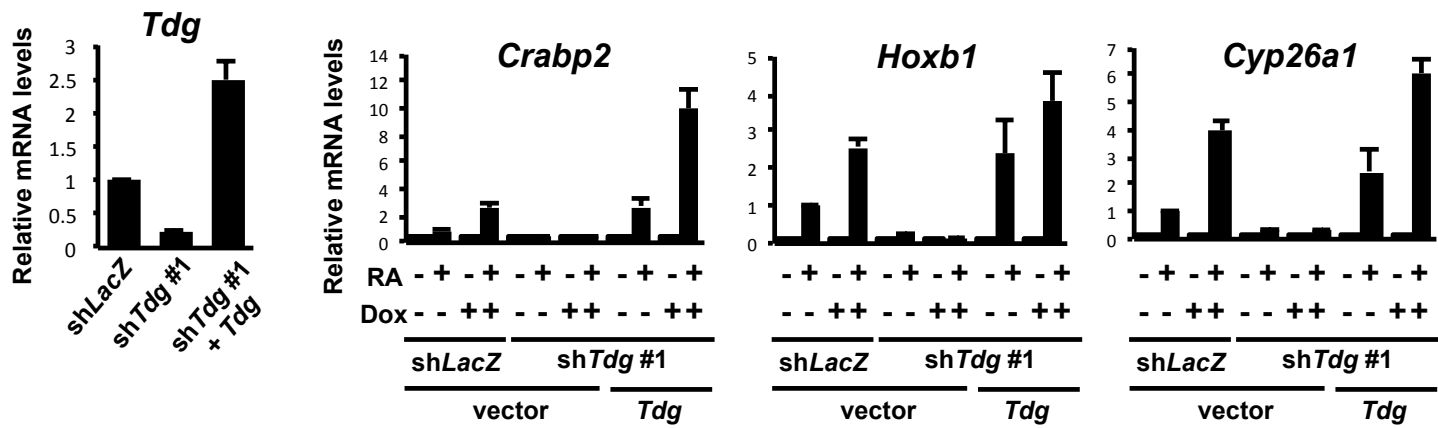

G
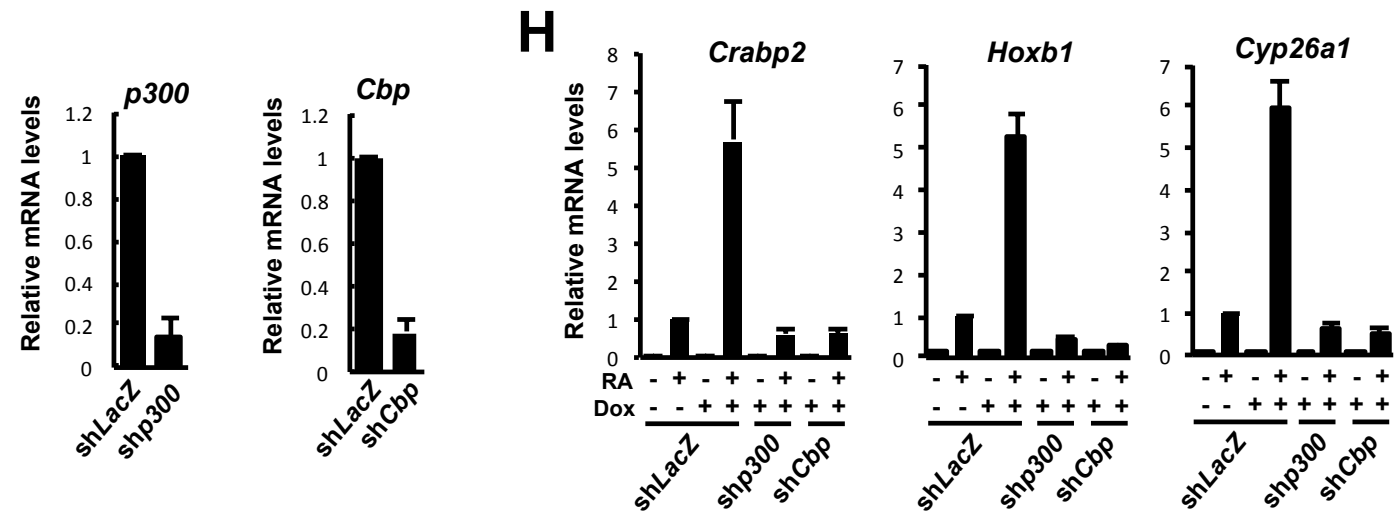


\section{Figure 6 - figure supplement 1}

RXRa, TDG, p300 and CBP are required for the marked enhancement of RA signalling in the absence of Casp8 expression, related to Figure 6.

(A) P19 cells expressing $\operatorname{sh} L a c Z$ or $\operatorname{sh} R x r a$ were subjected to qRT-PCR analysis for Rxra. Representative data are shown as means $\pm \operatorname{SEM}(\mathrm{n}=3)$.

(B) P19 cells expressing shLacZ or shRxra were cultured for 4 days with or without $1 \mu \mathrm{g} / \mathrm{ml}$ Dox and then treated with or without $1 \mu \mathrm{M}$ RA for $24 \mathrm{~h}$. Subsequently, qRT-PCR analysis of RA-induced genes, Crabp2, Hoxb1 and Cyp26a1, was carried out. Representative data are shown as means \pm SEM $(\mathrm{n}=3)$.

(C) Expression levels of $T d g$ were analyzed by qRT-PCR using P19 cells expressing sh $L a c Z$ or shTgd. Two shRNAs targeting different nucleotide sequences in $T d g$ (shTdg \#1 and shTdg \#2) were used. Representative data are shown as means $\pm \operatorname{SEM}(\mathrm{n}=3)$.

(D) P19 cells expressing shLacZ, shTdg\#1 or shTdg \#2 were cultured for 4 days with or without $1 \mu \mathrm{g} / \mathrm{ml}$ Dox and then treated with or without $1 \mu \mathrm{M}$ RA for $24 \mathrm{~h}$. Subsequently, qRTPCR analysis of RA-induced genes, Crabp2, Hoxb1 and Cyp26a1, was carried out. Representative data are shown as means \pm SEM $(n=3)$.

(E) P19 cells expressing $\operatorname{sh} L a c Z$ or sh $T d g \# 1$ together with or without Wt $T d g$ were subjected to qRT-PCR analysis for $T d g$. Representative data are shown as means $\pm \operatorname{SEM}(\mathrm{n}=3)$.

(F) P19 cells expressing $\operatorname{sh} L a c Z$ or $\operatorname{sh} T d g \# 1$ together with or without Wt $T d g$ were cultured with or without $1 \mu \mathrm{M}$ RA for $24 \mathrm{~h}$ in the presence or absence of $1 \mu \mathrm{g} / \mathrm{ml}$ Dox, and then subjected to qRT-PCR analysis for RA-inducible genes. vector, an empty vector.

Representative data are shown as means $\pm \operatorname{SEM}(\mathrm{n}=3)$.

(G) P19 cells expressing $\operatorname{sh} L a c Z$ or $\operatorname{sh} p 300$, and $\operatorname{sh} L a c Z$ or $\operatorname{sh} C b p$ were subjected to qRT-PCR analysis for $p 300$ and $C b p$, respectively. Representative data are shown as means \pm SEM $(\mathrm{n}=3)$.

(H) P19 cells expressing $\operatorname{sh} L a c Z$, shp300 or shCbp were cultured for 4 days with or without 1 $\mu \mathrm{g} / \mathrm{ml}$ Dox and then treated with or without $1 \mu \mathrm{M}$ RA for $24 \mathrm{~h}$. Subsequently, qRT-PCR analysis of RA-induced genes, Crabp2, Hoxb1 and Cyp26al, was carried out. Representative data are shown as means \pm SEM $(n=3)$. 


\section{RA Signaling Is Enhanced in Caspase- ${ }^{-/-}$Mouse Embryos}

Caspase-8-deficient $\left(\operatorname{Casp}^{-/}\right)$mouse embryos die at E11.5 with associated abnormal yolk sac vascularization, heart development and neural tube formation (Sakamaki et al., 2002). In mouse embryonic fibroblasts (MEFs) from $\operatorname{Casp}^{-/-}$mice (Figure 7A), RA-induced gene expression as well as $R A R E$-dependent transcription of luciferase was enhanced, compared to $\operatorname{Casp}^{+/+}$MEFs (Figures 7B,C). We also detected up-regulated transcription of RA-induced genes in Casp $^{-/-}$whole embryos at E10.5 by qRT-PCR (Figure 7D) and in situ hybridization analyses (Figure 7E). The up-regulation was more prominent in the embryo at E11.5. In situ hybridization analyses revealed that expression patterns of RA-inducible genes in $\operatorname{Casp} 8^{-/-}$ embryos were essentially the same as those of Wt embryos. Taken together, RA signaling was supposed to be enhanced in $\operatorname{Casp}^{\gamma^{-/}}$embryos as well as Casp $8 \mathrm{KD}$ cells.

In addition, a prominent RA response was observed in tissues of Casp $8^{-/}$embryos, heart, aorta-gonad-mesonephros (AGM) and neural tube, all of which were reported to be abnormal in Casp $^{-/-}$embryos (Figures 7F,G). These results seem to show the possibility that enhancement of RA signaling is at least in part involved in the embryonic letality of Casp $8^{-/}$ mice, although the embryonic letality of $\operatorname{Casp}^{-/-}$mice has been shown to be due to excess necroptosis (Dillon et al., 2016). A chemical inhibitor of RA signalling, BMS493 (le Maire et al., 2010), was intraperitoneally injected into the pregnant Casp 8 heterozygous $\left(\right.$ Casp $\left.8^{+/}\right)$ 
bioRxiv preprint doi: https://doi.org/10.1101/156901; this version posted June 28,2017 . The copyright holder for this preprint (which was

not certified by peer review) is the author/funder, who has granted bioRxiv a license to display the preprint in perpetuity. It is made available under aCC-BY 4.0 International license.

Someda $\mathrm{M}$ et al.

female mice intercrossed with $\operatorname{Casp} 8^{+/}$male mice (Figure 8A). The up-regulated expression of RA-specific genes in $\operatorname{Casp}^{-/}$embryos was partly but significantly suppressed by treatmetent with BMS493 (Figure 8B). BMS493-treated Casp8-deficient embryos were observed to be viable even at E11.5, and the characteristic abnormal phenotypes of yolk sac, neural tube and heart in Casp8-deficient embryos were also rescued by injection of BMS493 (Figures 8C-E). It should be noted, however, that BMS493-treated E12.5 Casp8-deficient embryos were not viable. Thus, chemical inhibition of RA signalling, which is enhanced in $\operatorname{Casp~}^{-/-}$embryos, delays, but does not completely inhibit, embryonic lethality of Casp8-deficient embryos. 


\section{Figure 7}

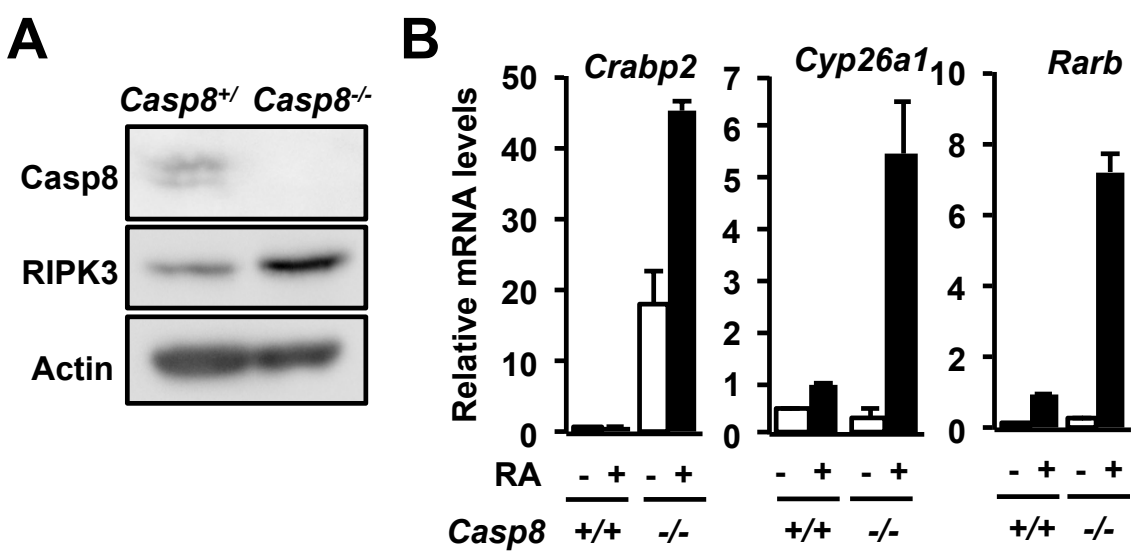

D

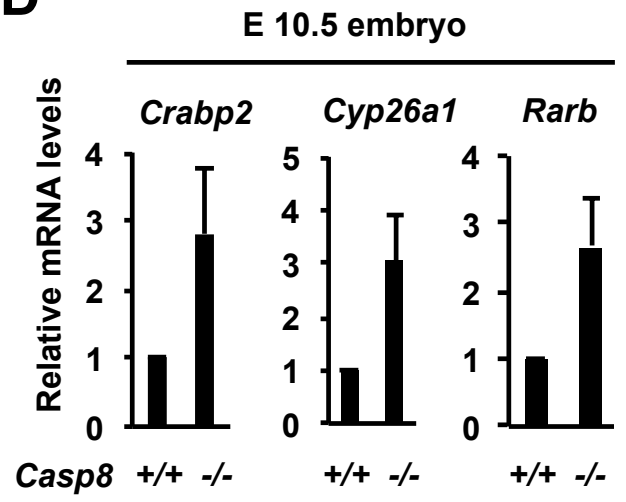

$\mathbf{F}$

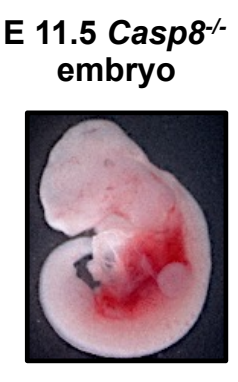

Raldh2

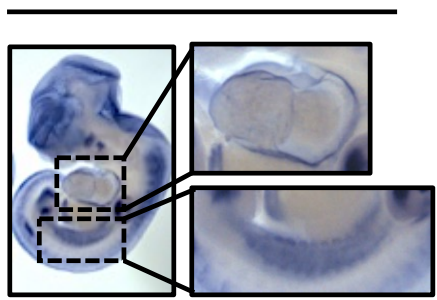

E
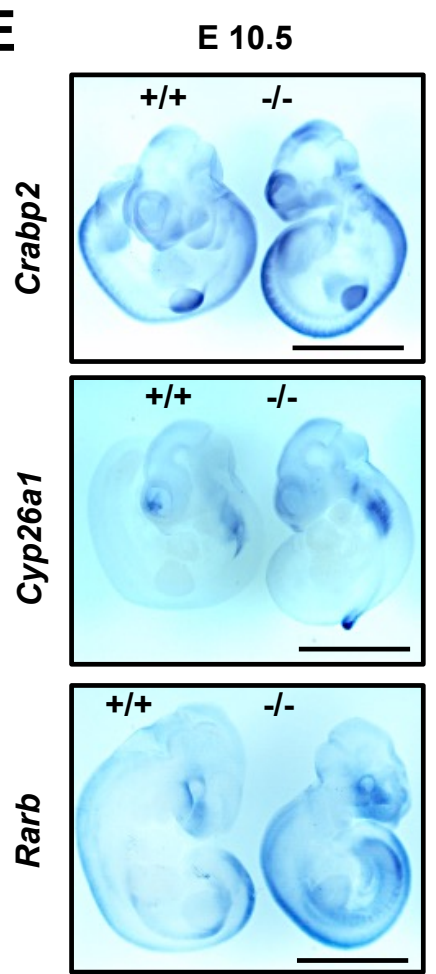

C RARE-luciferase

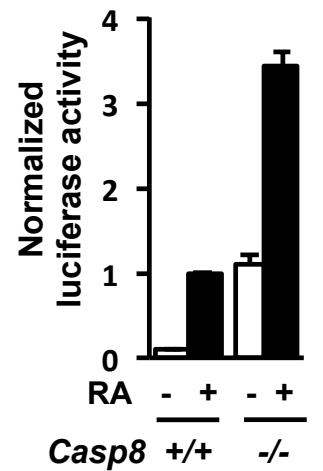

G E 11.5 neural tube

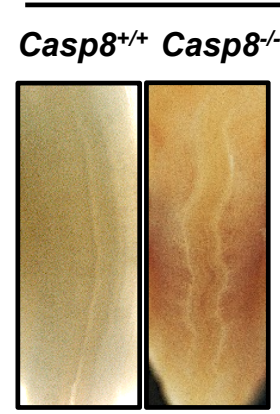

Casp8 $^{+/+}$Casp $^{-/-}$

Casp8 $^{+/+}$Casp 8- $^{-/-}$

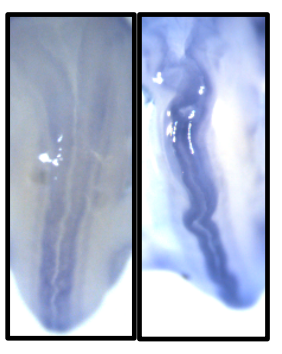

Rarb

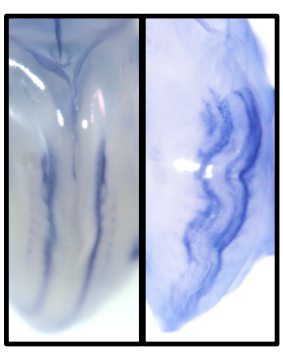

Raldh2
E 11.5
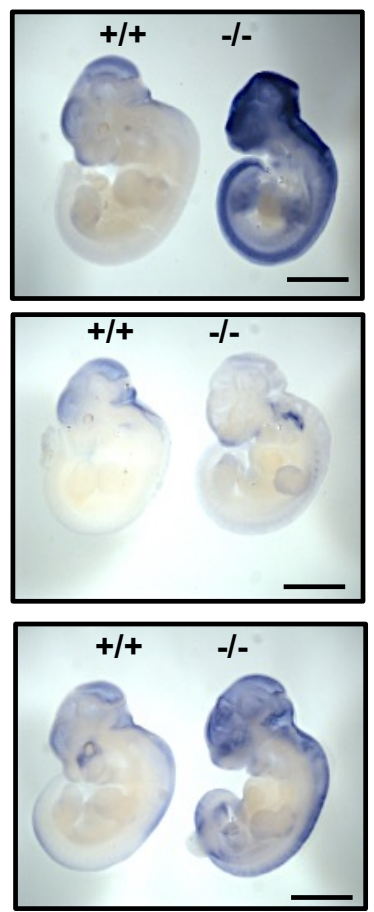


\section{Figure 7}

\section{RA signaling is enhanced in $\operatorname{Casp8}^{-/-}$mouse embryos.}

(A) Immortalized MEFs derived from Wt $\left(\operatorname{Casp}^{+/+}\right)$and $\operatorname{Casp} 8^{-/-}$embryos were subjected to western blot analysis for caspase-8 and RIPK3.

(B) qRT-PCR analysis of RA-induced genes, Crabp2, Cyp26al and Rarb, was carried out in $\operatorname{Casp}^{+/+}$and $\operatorname{Casp} 8^{-/-}$MEFs after treatment with or without $1 \mu \mathrm{M}$ RA for $24 \mathrm{~h}$.

Representative data are shown as means $\pm \operatorname{SEM}(n=3)$.

(C) Dual-luciferase reporter analysis of $R A R E$ was carried out using RA-treated $\operatorname{Casp} 8^{+/+}$and $\operatorname{Casp}^{+/-}$MEFs. Representative data are shown as means $\pm \operatorname{SEM}(\mathrm{n}=3)$.

(D) qRT-PCR analysis of RA-inducible genes, Crabp2, Cyp26a1 and Rarb, was performed in E10.5 Wt $\left(\operatorname{Casp}^{+/+}\right)$and $\operatorname{Casp}^{-/-}$littermates. RNA was extracted from whole embryos.

(E) Expressions of RA-inducible genes, Crabp2, Cyp26a1 and Rarb, in E10.5 or E11.5 Wt $\left(\operatorname{Casp}^{+/+}\right)$and $\operatorname{Casp} 8^{-/-}$littermates were detected by whole-mount in situ hybridization analysis. Scale bar, $2 \mathrm{~mm}$.

(F and G) Whole-mount in situ hybridization analysis of Rarb and Raldh2 was carried out using E11.5 Casp $^{-/-}$embryos. Views of heart and AGM (F), and neural tube (G) were shown. 


\section{Figure 8}

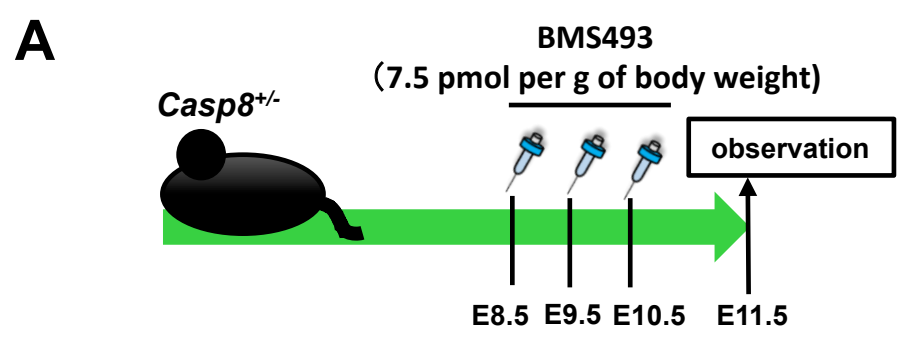

B
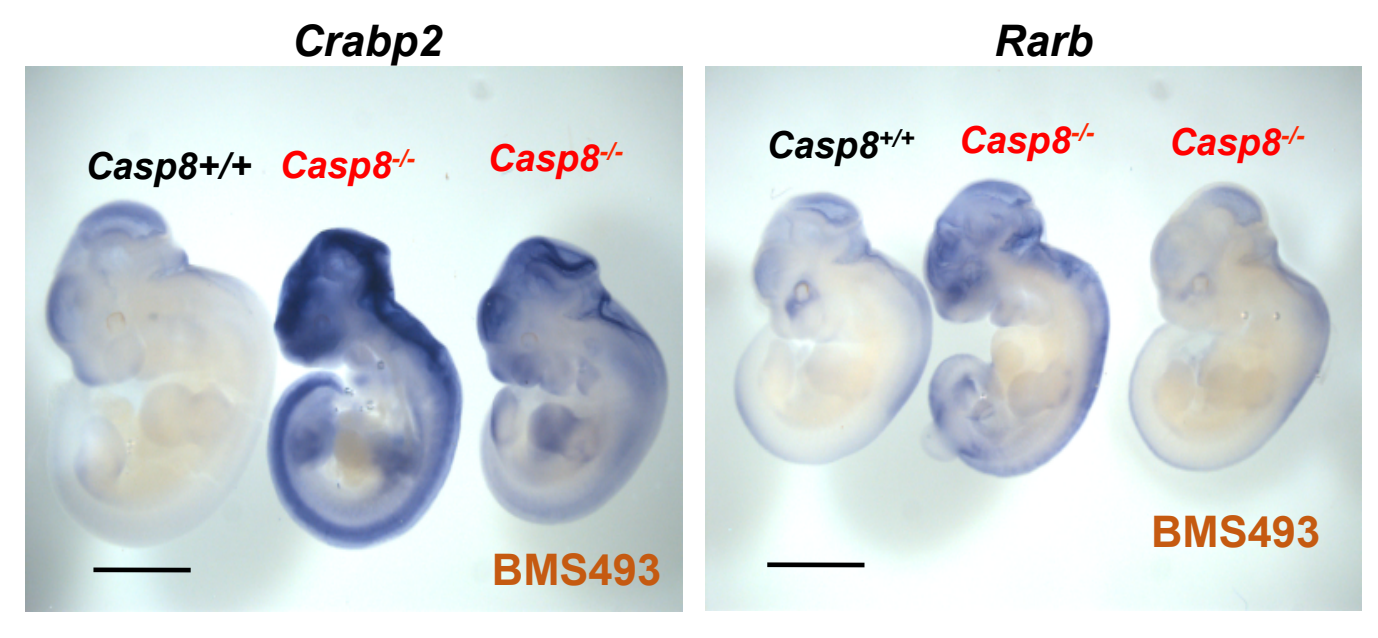

C
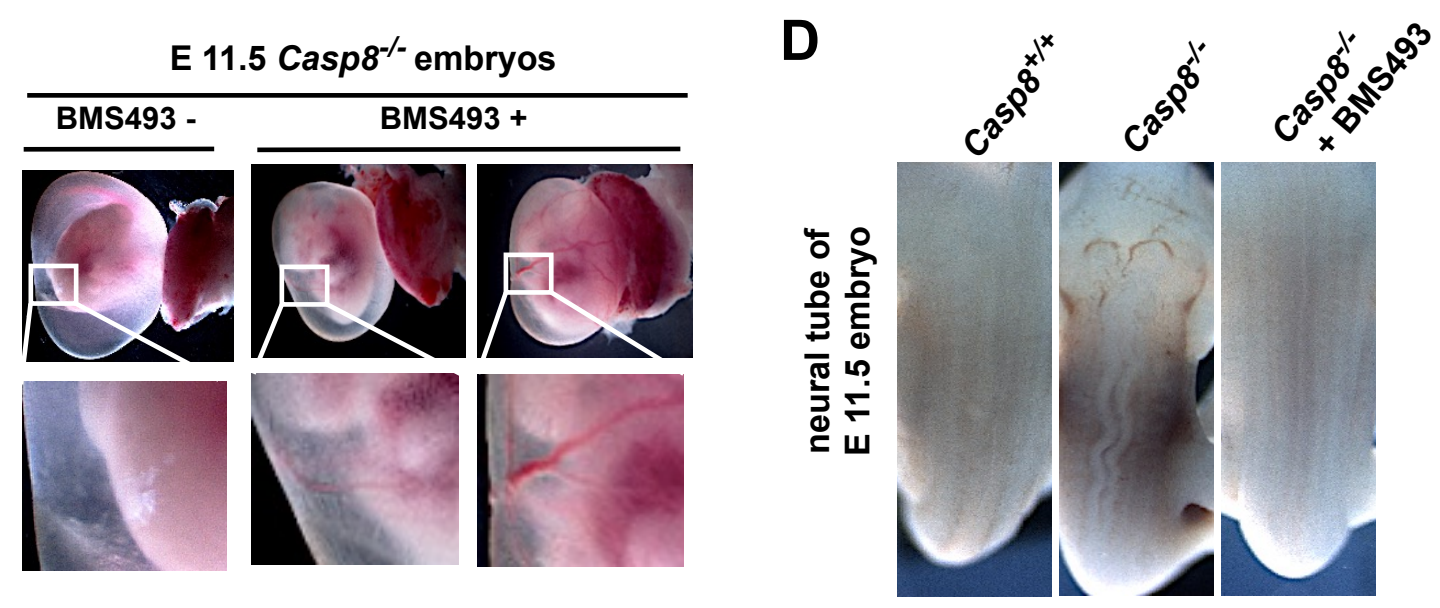

E

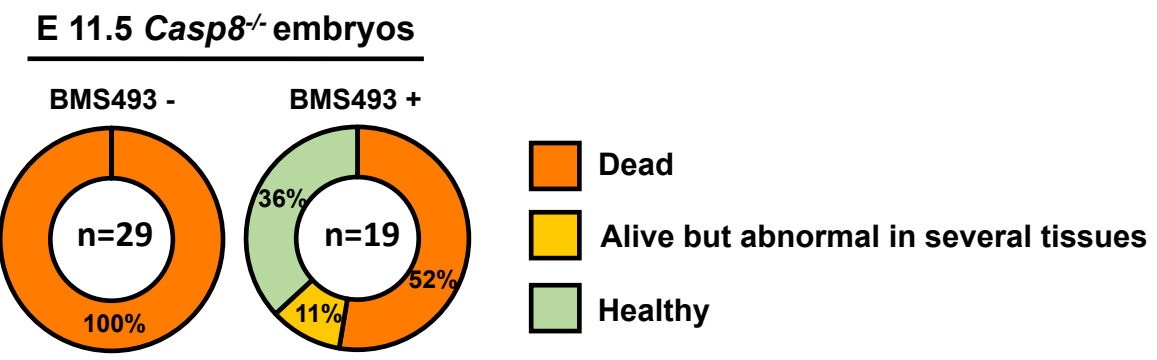




\section{Figure 8}

Marked enhancement of RA signaling in the absence of Casp8 is correlated with abnormality of $\operatorname{Casp}^{-/-}$embryos.

(A) Experimental design of intra-peritoneal injection of BMS493 into pregnant mice.

(B) Whole-mount in situ hybridization analysis of RA-inducible genes, Crabp2 and Rarb, was carried out for E11.5 Wt $\left(\operatorname{Casp}^{+/+}\right)$and $\operatorname{Casp}^{8^{-/-}}$littermates, and E11.5 $\operatorname{Casp}^{-/-}$embryos from pregnant $\operatorname{Casp} 8^{+/-}$mice treated with BMS493 (scale bar, $2 \mathrm{~mm}$ ).

(C) Views of yolk sac of E11.5 Casp $^{-/-}$embryos treated with or without BMS493.

(D) Views of neural tube of E11.5 $\operatorname{Casp}^{+/+}$and $\operatorname{Casp} 8^{-/-}$embryos, and $\operatorname{Casp} 8^{-/-}$embryo treated with BMS493.

(E) Quantification of viability and abnormalities of E11.5 Casp $^{8^{-/-}}$embryos treated with or without BMS493. 
bioRxiv preprint doi: https://doi.org/10.1101/156901; this version posted June 28, 2017. The copyright holder for this preprint (which was

not certified by peer review) is the author/funder, who has granted bioRxiv a license to display the preprint in perpetuity. It is made available under aCC-BY 4.0 International license.

Someda $\mathrm{M}$ et al.

\section{Discussion}

The enhancement of RA-specific genes expression in Casp 8 KD ES cells was significantly induced by not only $1 \mu \mathrm{M}$ RA (Figure 2A), but also 100 and $10 \mathrm{nM}$ RA (Figure2 - figure supplement 1A). Since the concentration of RA in mouse embryo tissues was reported to be approximately $25 \mathrm{nM}$ on average (Horton,. 1995), caspase-8 was supposed to suppress evident activation of RA signaling in a physiological condition. Indeed, up-regulated transcription of RA-induced genes was detected in $\operatorname{Casp}^{-/}$whole embryos by qRT-PCR (Figure 7D) and in situ hybridization analyses (Figure 7E). Furthermore, expressions of shCasp8-resistant Wt Casp8 significantly inhibited the evident activation of RA signaling by Casp8 KD ES cells (Figure2 - figure supplement 4)). Based on all the in vitro and in vivo findings in this manuscript, suppression of caspase- 8 or FADD expression, or caspase- 8 activity generally enhances RA signaling/RARE-dependent transcription through nuclear translocation of RIPK1 and RIPK3 followed by their association with RARs in a coactivator complex (Figure 9). 


\section{Figure 9}

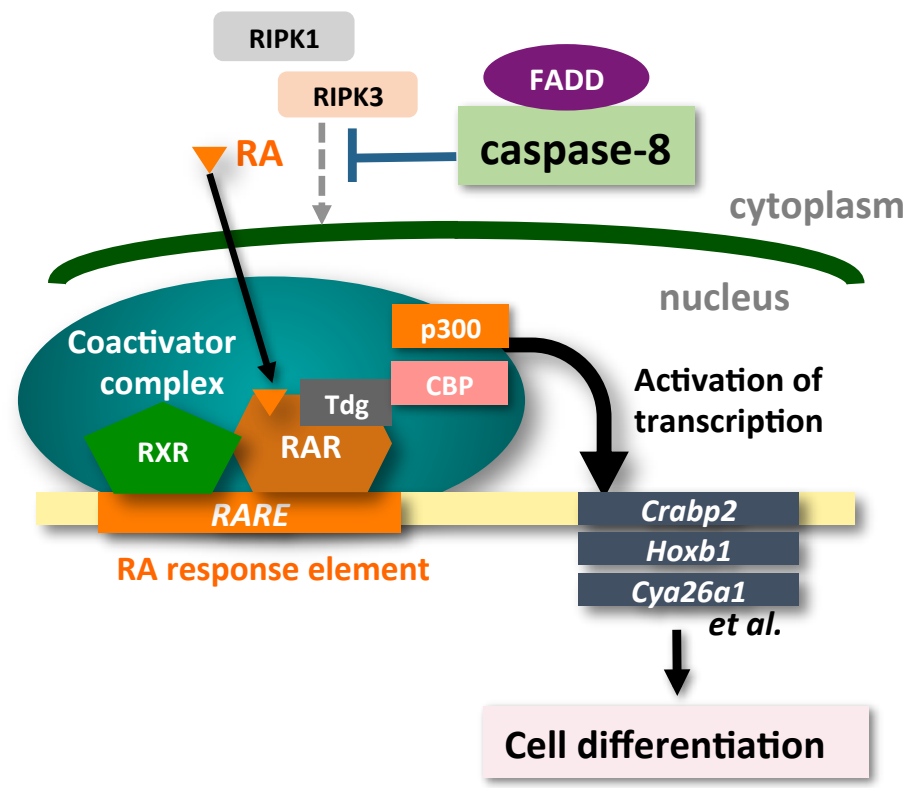

in the absence of caspase-8 or FADD

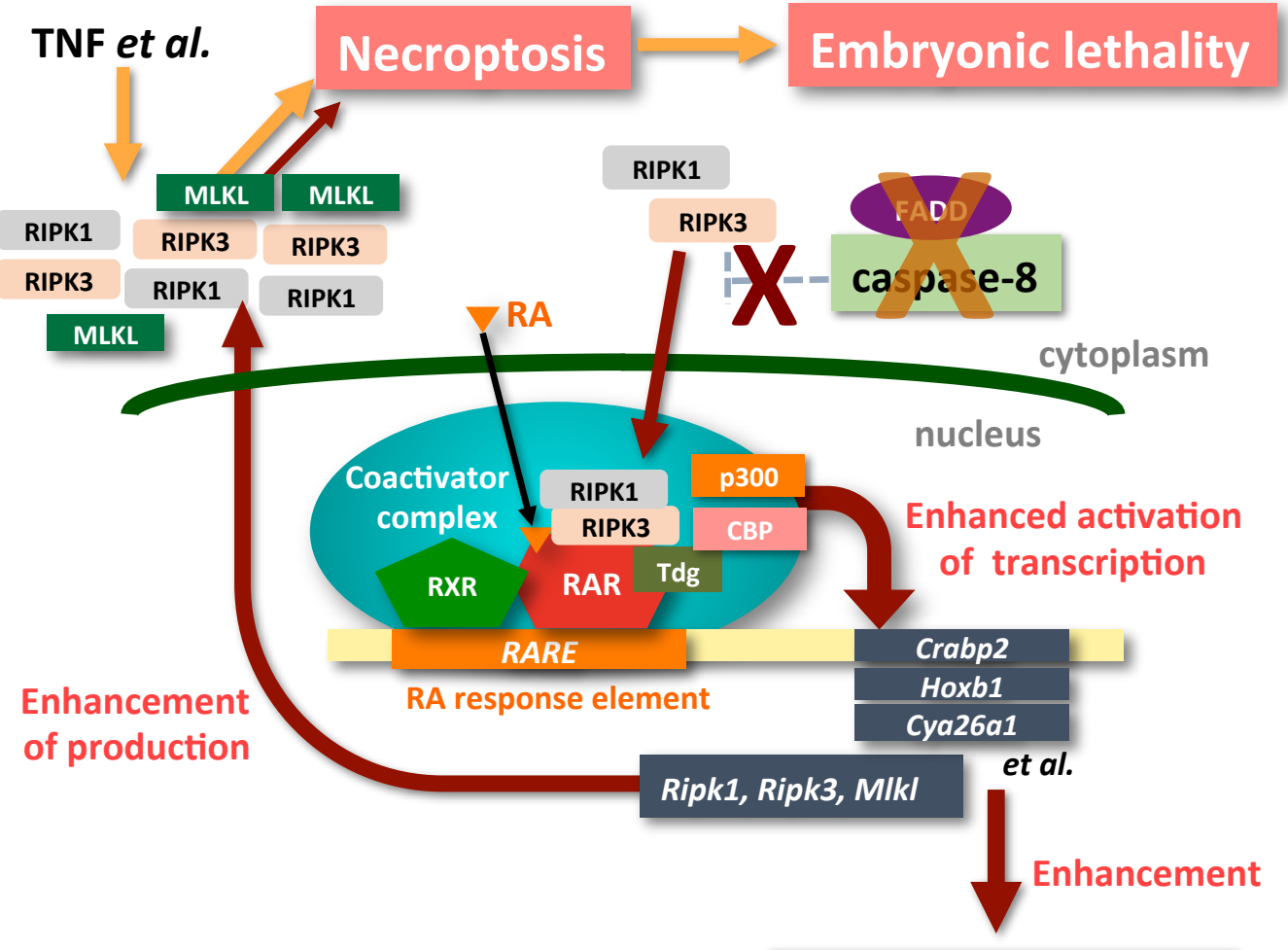

\section{Cell differentiation}


bioRxiv preprint doi: https://doi.org/10.1101/156901; this version posted June 28,2017 . The copyright holder for this preprint (which was

not certified by peer review) is the author/funder, who has granted bioRxiv a license to display the preprint in perpetuity. It is made available under aCC-BY 4.0 International license.

Someda $\mathrm{M}$ et al.

\section{Figure 9.}

A model of the RA signalling in the presence and absence of caspase-8.

Brown directional lines indicate signaling pathways induced and/or enhanced by the absence of caspase- 8 activity/expression or FADD expression. 
bioRxiv preprint doi: https://doi.org/10.1101/156901; this version posted June 28,2017 . The copyright holder for this preprint (which was

not certified by peer review) is the author/funder, who has granted bioRxiv a license to display the preprint in perpetuity. It is made available under aCC-BY 4.0 International license.

Someda $\mathrm{M}$ et al.

Induced KD of Casp8 expression in EBs derived form TetR-shCasp8 ES cells was shown to sensitize the cells to RA-induced necroptosis (Figure 3C). RA-induced necroptosis was observed in EBs derived from Casp 8 KD ES and P19 cells, but not in either Casp 8 KD ES and P19 cells before EB formation, SK-N-SH cells or HL60 cells. RA-induced necroptosis seems to be induced in only EB or its related early embryo. In fact, the cell lines, which were insensitive to RA-induced necroptosis, were sensitized to apoptosis by strong stimulation with RA (data not shown). Yet-to-be-defined mechanism(s) in EBs might contribute the conversion of response to RA, from apoptosis to necroptosis. Necroptosis was induced in RA-treated Casp 8 KD EBs through enhanced expression of Ripk1, Ripk3 and Mlkl (Figure 3D). RARs were reported to be able to directly bind to a $R A R E$-like sequence in the promoter region of Ripk1 in RA-treated ES cells (Moutier et al., 2012). The RA-induced up-regulation of Ripk1 expression in Casp8 KD EBs might be directly mediated by RARs during RA-induced differentiation of cells in EBs. However, it has not been determined yet whether the RA-induced up-regulation of Ripk3 and Mlkl are directly mediated RARs or not.

$\operatorname{Casp}^{-/}$embryos die at E10.5-E11.5 with associated abnormal yolk sac vascularization, heart development and neural tube formation ( Varfolomeev et al., 1998; Sakamaki et al., 2002). The embryonic lethality of Casp $8^{-/}$embryos is rescued by not only depletion of Ripk3 (Kaiser et al., 2011) but also knock-in of kinase-negative K51A Ripk3 (Mandal et al., 2014), 
indicating that kinase activity of RIPK3, which is indispensable for induction of necroptosis, is required for embryonic lethality of $\mathrm{Casp}^{-/-}$embryos. In contrast, RIPK3 is, but kinase activity of RIPK3 is not, required for the enhancement of RA signaling in Casp 8 KD ES cells (Figures 2G). In addtion, $\operatorname{Casp}^{-/-} M l k l^{-/}$mice were recently reported to be viable and to mature into fertile adults (Alvarez-Diaz et al., 2016). Thus, MLKL and kinase activity of RIPK3, both of which are required for the induction of necroptosis but not for the enhancemnt of RA signaling in Casp $8 \mathrm{KD}$ cells, are indispensable for embryonic letality of Casp $8^{-/}$ embryos. Taken togetger, the embryonic letality of $\operatorname{Casp}^{-/-}$mice is due to excess necroptosis (Dillon et al., 2016), but not due to the enhancement of RA-induced differentiation. Interestingly, $\operatorname{Casp}^{-/-} \mathrm{Mlkl}^{-/}$mice succumbed significantly earlier than $\operatorname{Casp~}^{-/-} \mathrm{Ripk}^{-/-}$mice due to a more rapid onset of severe lymphadenopathy and autoimmune pathology (Alvarez-Diaz et al., 2016), suggesting that biological activity other than necroptosis-inducing activity of RIPK3 is involved in the rapid onset of severe autoimmunity in $\mathrm{Casp}^{-/-} \mathrm{Mlkl}^{-/-}$ mice. It would be interesting to analyze whether the RIPK3-dependent enhancement of RA signaling is implicated in the rapid onset of severe autoimmunity in $\operatorname{Casp~}^{{ }^{-/}} \mathrm{Mlkl}^{-/-}$mice.

Elimination of TNFR1 from Casp $8^{-/}$embryos was shown to delay embryonic lethality from E10.5 until E16.5 (Dillon et al., 2014), indicating that TNFR1-mediated necroptosis plays an essential role in the embryonic letality of $\operatorname{Casp}^{-/-}$mice around E10.5. Hence 
bioRxiv preprint doi: https://doi.org/10.1101/156901; this version posted June 28, 2017. The copyright holder for this preprint (which was

not certified by peer review) is the author/funder, who has granted bioRxiv a license to display the preprint in perpetuity. It is made available under aCC-BY 4.0 International license.

Someda $\mathrm{M}$ et al.

RA-induced necroptosis should not be required for the embryonic letality of $\operatorname{Casp} 8^{-/}$mice around E10.5. However, TNF was shown to induce necroptosis in RA-treated but not RA-untreated Casp8 KD EBs (Figure 3F), suggesting that enhancement of RA signaling contributes sensitization of cells in $C a s p 8^{-/}$embryo to TNF-induced necroptosis. In addition, chemical inhibition of RA signaling delayed embryonic letality of $\operatorname{Casp}^{-/-}$mice until E12.5 (Figures 8E). Taken together, we suppose that ripkl, ripk3 and $m l k l$ expressions are enhanced by RA in $\operatorname{Casp}^{-/-}$embryos, and their increased expressions might be partly involved in the embryonic letality of $\operatorname{Casp}^{-/}$mice around E10.5 through enhancing the sensitivity to TNF-induced necroptosis (Figure 9).

Caspase- 8 and RIPK were shown to regulate sensitivity to RA signalling in not only mouse ES cells but also human cancer cell lines (Figure2 - figure supplement 3). Intriguingly, acute promyelocytic leukemia (APL) was reported to be dramatically improved by co-treatment with RA and a caspase inhibitor when compared with treatment with only RA (Ablain et al., 2014). Taken together, our study contributes to a deeper understanding of the nexus of caspase- 8 and RA signaling in cell death, cell differentiation, development, stem cell fate, ontogenesis, and the fate of cancer cells. 


\section{Materials and methods}

Mice. C57BL/6 mice were purchased from CLEA Japan. Casp $8^{-/-}$mice were generated as described previously (Sakamaki et al., 2002). C57BL/6 Casp $^{-/-}$mice were bred and maintained in specific pathogen-free conditions. All experiments in this study were performed according to the guidelines for animal treatment at the institute of Laboratory Animals (Kyoto University).

Cell culture. TT2 mouse ES cells were maintained on mitomycin C-treated MEFs in Dulbecco's modified Eagle's medium (DMEM, Gibco) supplemented with 1\% fetal bovine serum (JRH Bioscience), 10\% knockout serum replacement (KSR, Gibco), $2 \mathrm{mM}$ L-glutamine, $0.1 \mathrm{mM} \beta$-mercaptoethanol, $0.1 \mathrm{mM}$ non-essential amino acids (Gibco), $1 \mathrm{mM}$ sodium pyruvate (Gibco) and $1000 \mathrm{U} / \mathrm{ml}$ LIF (CHEMICOM). MEFs, P19 cells, SK-N-SH cells and HEC293T cells were cultured in Dulbecco's modified Eagle's medium (DMEM, Nacalai Tesque Inc.) supplemented with 10\% fetal bovine serum (Sigma), $100 \mathrm{U} / \mathrm{ml}$ penicillin and $100 \mu \mathrm{g} / \mathrm{ml}$ streptomycin (Nacalai Tesque Inc.). HL60 cells, a kind gift from K. Inaba (Kyoto University), were cultured in suspension culture in RPMI 1640 (Nacalai Tesque Inc.). All cells were cultured at $37^{\circ} \mathrm{C}$ in $5 \% \mathrm{CO}_{2}$. 


\section{Plasmids, lentiviral expression vectors, and shRNA expression system.}

$\mathrm{p} R A R E 3$-Luciferase and an expression vector carrying human RAR $\alpha \mathrm{cDNA}$ were kind gifts from A. Kakizuka (Kyoto University). Lentiviral vectors, originally provided by H. Miyoshi (RIKEN), were prepared as described previously ${ }^{31}$. For expression of mouse Casp 8 with shCasp8-resistant silent mutations, the corresponding cDNA fragment after site-directed mutagenesis was subcloned into pCSII-PGK-MCS-IRES-Hyg. For expression of mouse $T d g$ and mouse Ripk3 with shRipk3-resistant silent mutations, their corresponding cDNA fragments were subcloned into pCSII-PGK-3xFlag-MCS-IRES-Hyg. To generate stably shRNA-expressing cells, we utilized lentivirus vectors, pCSII-U6-MCS and pCSII-U6-MCS-puro (kind gifts from Y. Satoh and M. Matsuoka, Kyoto University). shRNA-encoding DNA oligonucleotides were inserted into these vectors. To achieve the specific knockdown of mouse Casp 8 or Fadd, the tetracycline inducible shRNA expression system (Tet-On shRNA system) with lentivirus based vectors (pCSII-EF-TetR-IRES-puro and pCSII-U6tet-shCasp8 or shFadd-PGK-neo) was utilized in TT2 mouse ES and P19 cells as previously described (Kobayashi and Yonehara, 2009; Kikuchi et al., 2012). 
Someda $\mathrm{M}$ et al.

The following primer sequences of shRNA were used:

\begin{tabular}{lll}
\hline Target Gene & Accession number & Sequence (5' to 3') \\
\hline Casp8 (mouse) & NM_009812.2 & GGAAGATCGAGGATTATGAAA \\
Fadd (mouse) & NM_010175.5 & GCGAGCGCGTGAGCAAACGAA \\
Ripk3 (mouse) & NM_019955.2 & TATGGTTATTCTTCGTAATGA \\
Ripkl (mouse) & NM_009068.3 & CCTGAATGACATCAATGCAAA \\
Mlkl (mouse) \#1 & NM_029005.2 & TCCCAACATCTTGCGTATATT \\
Mlkl (mouse) \#2 & NM_029005.2 & AGATCCAGTTCAACGATATAT \\
Rxra (mouse) & NM_011305.3 & CCTGTTCAACCCTGACTCTAA \\
Tdg (mouse) \#1 & NM_011561.2 & AAATGTCAGGAAGAGTCTTGG \\
Tdg (mouse) \#2 & NM_011561.2 & TTAACAGCCATCTTCTTTGCG \\
$p 300$ (mouse) & NM_177821.6 & CCAACAGGAATGACTACCAAT \\
Cbp (mouse) & NM_001025432.1 & TAACTCTGGCCATAGCTTAAT \\
CASP8 (human) & NM_001228.4 & GAATCACAGACTTTGGACAAA \\
GFP & & AAGCAGCACGACTTCTTCAAG \\
LacZ & V00296.1 & AAGGCCAGACGCGAATTAT \\
\hline
\end{tabular}

RA treatment for quantification of RA-induced genes. Cells were treated with $1 \mu \mathrm{M}, 100$ $\mathrm{nM}, 10 \mathrm{nM}$ or $1 \mathrm{nM}$ RA (Sigma) for $24 \mathrm{~h}$, and then expression levels of RA-induced genes were quantified.. In the case of cells with a Tet-On shRNA system, cells were cultured with or without $1 \mu \mathrm{g} / \mathrm{ml}$ Dox for 4 days, and then treated with or without $1 \mathrm{RA}$ for $24 \mathrm{~h}$ in the presence of Dox. To analyze expression of genes directly induced by RA, cells were treated with RA for only $24 \mathrm{~h}$.

Differentiation of ES cells and P19 cells through EB formation. After Tet-On shCasp8 or shFadd ES cells were cultured with or without $1 \mu \mathrm{g} / \mathrm{ml}$ Dox for 2 days, single-cell 
bioRxiv preprint doi: https://doi.org/10.1101/156901; this version posted June 28,2017 . The copyright holder for this preprint (which was

not certified by peer review) is the author/funder, who has granted bioRxiv a license to display the preprint in perpetuity. It is made available under aCC-BY 4.0 International license.

Someda $\mathrm{M}$ et al.

suspensions were prepared by treatment with trypsin-EDTA (Nacalai Tesque Inc.). To form

EBs, 3 × $10^{6}$ cells were seeded per well in low-cell-adhesion 96-well plates (Thermo

SCIENTIFIC) in Glasgow's Minimum Essential Medium (GMEM, Gibco) supplemented

with $10 \%$ knockout serum replacement (KSR, Gibco), 2mM L-glutamine, $0.1 \mathrm{mM}$

$\beta$-mercaptoethanol, $0.1 \mathrm{mM}$ non-essential amino acids (Gibco) and $1 \mathrm{mM}$ sodium pyruvate

(Gibco) (ES differentiation medium) in the presence of Dox. Two days after seeding, medium

was changed to ES differentiation medium supplemented with or without $1 \mu \mathrm{M}$ RA. After 2

days cultivation, formed EBs were transferred to collagen type I-coated chamber slides

(Becton Dickinson), cultured for 4 days in ES differentiation medium supplemented with or

without $1 \mu \mathrm{M}$ RA (RA treatment was for 6 days in all.), and subjected to immunohistochemical analysis. To induce significant differentiation of cells through EB formation, 6 days treatment with RA was necessary.

For RA-induced neural differentiation of Tet-On shCasp 8 P19 cells, cells were treated with or without $1 \mu \mathrm{g} / \mathrm{ml}$ Dox for 4 days, and single-cell suspensions were prepared by treatment with trypsin-EDTA (Nacalai Tesque Inc.). To form EBs, 1 x $10^{6}$ cells were seeded per $10 \mathrm{~cm}$ non-treated dish (IWAKI) in DMEM (Nacalai Tesque Inc.) supplemented with 10\% fetal bovine serum (Sigma), $100 \mathrm{U} / \mathrm{ml}$ penicillin, and $100 \mu \mathrm{g} / \mathrm{ml}$ streptomycin (Nacalai Tesque Inc.), and cultured for 2-6 days with or without $1 \mu \mathrm{M}$ RA. 


\section{LDH release assay}

After Tet-On shCasp8 or shCasp8/Ripk3 ES cells were cultured with or without $1 \mu \mathrm{g} / \mathrm{ml}$ Dox for 2 days, single-cell suspensions were prepared by treatment with trypsin-EDTA (Nacalai Tesque Inc.). To form EBs, 1.6 x $10^{5}$ cells were seeded per well in non-treated 6-well plates (IWAKI) in ES differentiation medium in the presence of Dox. Two days after seeding, the medium was changed to ES differentiation medium supplemented with or without $1 \mu \mathrm{M}$ RA and $1 \mu \mathrm{g} / \mathrm{ml}$ Dox. To inhibit necroptosis, cells were cultured with $30 \mu \mathrm{M}$ Nec1 (Enzo Life Science) thereafter. After a further 2-day cultivation with or without RA, Dox and Nec-1, the LDH release assay was performed using a Cytotoxicity Detection $\mathrm{Kit}^{\text {PLUS }}$ (Roche) in accordance with manufacturer's instructions. At least 3 biological experiments were carried out and data are presented as means \pm s.d.

Western blot analysis and immunoprecipitation. For western blot analysis, cells were lysed in ice-cold lysis buffer $(20 \mathrm{mM}$ Tris-HCl, pH7.4, with 10\% glycerol, $1 \%$ Triton $\mathrm{X}-100,0.5 \%$ Nonidet P-40, $150 \mathrm{mM} \mathrm{NaCl}$, and $1 \mathrm{mM}$ EDTA) containing a protease inhibitor cocktail (Nacalai Tesque Inc.). Cell lysates were resolved by sodium dodecyl sulfate-polyacrylamide gel electrophoresis (SDS-PAGE) and analyzed by western blot analysis as described 
bioRxiv preprint doi: https://doi.org/10.1101/156901; this version posted June 28,2017 . The copyright holder for this preprint (which was

not certified by peer review) is the author/funder, who has granted bioRxiv a license to display the preprint in perpetuity. It is made available under aCC-BY 4.0 International license.

Someda $\mathrm{M}$ et al.

previously (Minamida et al., 2014). For immunoprecipitation, cells were lysed in RIPA buffer (50 mM Tris-HCl, $\mathrm{pH} 7.5,150 \mathrm{mM} \mathrm{NaCl}, 1 \mathrm{mM}$ EDTA, 1\% NP-40, and 0.5\% sodium deoxycholate containing a protease inhibitor cocktail (Nacalai Tesque Inc.), and immunoprecipitation was performed following standard protocols. Immunoprecipitates were resolved by SDS-PAGE and analyzed by western blotting.

The antibodies used for western blot analyses and immunoprecipitation in this study were anti-mouse caspase-8 (ALX-804-447-C100, Enzo Life Science), anti-RIPK1 (610458, BD Transduction Laboratories), anti-mouse RIPK3 (ADI-905-242-100, Enzo Life Science), anti-human caspase-8 (M032-3, MBL), anti-Flag M2 (F3165, Sigma), anti-MLKL (MABC604, MERCK MILLIPORE), anti-RAR (M-454, Santa Cruz), anti-Histone H3 (601901, BioLegend), and anti-actin (MAB1501, MERCK MILLIPORE).

Immunocytochemistry and whole-mount in situ hybridization. Cells in chamber slides were fixed with 4\% paraformaldehyde (Nacalai Tesque Inc.) in PBS for $15 \mathrm{~min}$ and permeabilized by 3 successive treatments with $0.3 \%$ Triton X-100 (Nacalai Tesque Inc.) in PBS for $2 \mathrm{~h}$. Cells were treated with primary antibodies for $12 \mathrm{~h}$ at $4^{\circ} \mathrm{C}$, washed 3 times with $0.05 \%$ Tween-20 in PBS, and then treated with Alexa Fluor ${ }^{\circledR}$ 488-conjugated anti-mouse IgG (Molecular Probes) for $1 \mathrm{~h}$. Fixed cells were washed 3 times with $0.05 \%$ Tween-20 in PBS 
bioRxiv preprint doi: https://doi.org/10.1101/156901; this version posted June 28, 2017. The copyright holder for this preprint (which was

not certified by peer review) is the author/funder, who has granted bioRxiv a license to display the preprint in perpetuity. It is made available under aCC-BY 4.0 International license.

Someda $\mathrm{M}$ et al.

and mounted with VECTASHIELD Mounting Medium with DAPI (Vector Laboratories).

Cells were analyzed under a confocal fluorescent microscope (OLYMPUS). The antibodies for immunocytochemistry used in this study were anti-Flag M2 (F3165, Sigma) and anti-Tuj1 (MAB1637, MECK MILLIPORE). Whole-mount in situ hybridization was performed as described previously (Harima et al., 2013).

Dual-Luciferase assay. Tet-On shGFP or Tet-On shCasp 8 TT2 mouse ES cells transfected with $\mathrm{pRARE3-Luciferase}$ and $\mathrm{pTK}$-Renilla luciferase were cultured with or without $1 \mu \mathrm{g} / \mathrm{ml}$ Dox for 5 days and then treated with or without $1 \mu \mathrm{M}$ RA for $24 \mathrm{~h}$. The Dual-Luciferase assay was performed using a dual-luciferase assay kit (Promega) in accordance with the manufacturer's instructions. At least 3 biological experiments were carried out and data are presented as means \pm s.d.

qRT-PCR. Total RNA was extracted using Sepasol ${ }^{\circledR}$-RNA Super G (Nacalai Tesque Inc.) according to the manufacturer's instructions. The reverse transcription (RT) reaction was performed using a ReverTra Ace ${ }^{\circledR}$ qRT-PCR Master Mix (TOYOBO) according to the manufacturer's instructions. RT products were analyzed using a THUNDERBIRD ${ }^{\circledR}$ qPCR Mix (TOYOBO) and the StepOne real-time PCR system (Applied Biosystems) with the 
Someda $\mathrm{M}$ et al.

primer sets listed bellow according to the manufacturer's instructions. The expression level of each mRNA was normalized to that of mouse or human GAPDH. At least 3 biological experiments were carried out and data are presented as means \pm s.d.

The following primer sequences for qRT-PCR were used:

\begin{tabular}{|c|c|c|c|}
\hline Target Gene & Accession number & Forward primer sequence ( $5^{\prime}$ to $3^{\prime}$ ) & Reverse primer sequence ( $5^{\prime}$ to $3^{\prime}$ ) \\
\hline Casp8 (mouse) & NM_009812.2 & CTAGACTGCAACCGA GAGG & GCAGGCTCAAGTCATCTTCC \\
\hline Fadd (mouse) & NM_010175.5 & GGGGAGAGACTGGAAAAGAC & TTACCCGCTCACTCAGACTT \\
\hline Ripk3 (mouse) & NM_019955.2 & CACATACTTTACCCTTCAGA & TCAGAACAGTTGTTGAAGAC \\
\hline Ripk1 (mouse) & NM_009068.3 & CGTGAGAATATTAAGAGTGC & TGTACCTGTAGTTCCAAATC \\
\hline Mlkl (mouse) & NM_029005.2 & GACCAAACTGAAGACAAGTA & СТСАСТАТТССААСАСТТТС \\
\hline Crabp2 (mouse) & NM_007759.2 & GAAATGGGAGAGTGGAAACA & GCTCTCCATCATTGGTCAG \\
\hline Hoxb1 (mouse) & NM_008266.5 & GTCTGCTCAGTTCCGTAT & TATTATTCTGTGGGTCAGTC \\
\hline Cyp26al (mouse) & NM_007811.2 & GACGTCACTGATCACTTACC & GACATCACTGATCACTTACC \\
\hline Rarb (mouse) & NM_001289761.1 & AACTCAGATGCACAATGCTG & TTTGTTGGTTCCTCAAGGTC \\
\hline Rara (mouse) & NM_009024.2 & AGTTCCGAAGAGATAGTACC & CGTATACACCATGTTCTTCT \\
\hline Rarc (mouse) & NM_011244.4 & CAGGACACTATGACATTCTC & GAGGCAGATAGCACTAAGTA \\
\hline Rxra (mouse) & NM_011305.3 & CTCCATAGCTGTGAAAGAT & TTAGACACCAGCTCTGTTAG \\
\hline Raldh2 (mouse) & NM_009022.4 & CAAGCTCTCCATACTGTTAC & ACATTCTATACTGTGGGTTG \\
\hline p300 (mouse) & NM_177821.6 & TGGACTACCCTATCAAGTAA & CATAGGACTAGCACTCATGT \\
\hline$C b p$ (mouse) & NM_001025432.1 & AAGCTAAAGAGGAAGAAGAG & TAGAGTGCTTCTAGAGTTGG \\
\hline Tujl (mouse) & NM_023279.2 & GCTCAAAATGTCATCCACCT & CTCGGTGAACTCCATCTCAT \\
\hline Nestin (mouse) & NM_016701.3 & GGTCTGAGTCTGCTTCCTTG & CAGCCTGCTCTAGTCCATTC \\
\hline Oct4 (mouse) & NM_013633.3 & CCGACAACAATGAGAACCTT & ACATGGTCTCCAGACTCCAC \\
\hline Gapdh (mouse) & NM_001289726.1 & GATGACATCAAGAAGGTGGTGA & TGCTGTAGCCCGTATTCATTGTC \\
\hline CASP8 (human) & NM_001228.4 & GGTATACCTGTTGAGACTGA & GGAAACACAGTTATTCACAG \\
\hline$C R A B P 2$ (human) & NM_001878.3 & GGAGACACTTTCTACATCAA & CСATTTTATTCTCACTTACC \\
\hline CYP26A1 (human) & NM_000783.3 & CACATCTCTGATCACTTACC & GAAGGGTCTCCTTAATAACA \\
\hline$R A R B$ (human) & NM_001290276.1 & CCGAGATAAGAACTGTGTTA & ACTCAGCTGTCATTTCATAG \\
\hline TUJ1 (human) & NM_001197181.1 & CAAGTTCTGGGAAGTCAT & CAAGTTCTGGGAAGTCAT \\
\hline$C D 11 b$ (human) & NM_001145808.1 & TCTCTTTGATGCAGTACTCT & GATGTTAAACAGCTCTCGTA \\
\hline GAPDH (human) & NM_002046.5 & TCCACCACCCTGTTGCTGTA & ACCACAGTCCATGCCATCAC \\
\hline
\end{tabular}


bioRxiv preprint doi: https://doi.org/10.1101/156901; this version posted June 28, 2017. The copyright holder for this preprint (which was

not certified by peer review) is the author/funder, who has granted bioRxiv a license to display the preprint in perpetuity. It is made available under aCC-BY 4.0 International license.

Someda $\mathrm{M}$ et al.

Flow cytometric analysis. HL60 cells expressing $\operatorname{sh} L a c Z$ or $\operatorname{shCasp} 8$ were cultured with or without $1 \mu \mathrm{M}$ RA for 3 days and then stained with FITC-conjugated anti-CD11b antibody (eBioscience) for 30 min. Flow cytometric analysis was performed with a FACS canto2 (BD Biosciences).

ChIP analysis. ChIP analyses were performed as previously described (Lee et al., 2006). In brief, quantitative PCR was performed using a THUNDERBIRD ${ }^{\circledR}$ qPCR Mix (TOYOBO) and the StepOne real-time PCR system (Applied Biosystems) with the primer listed bellow. The antibodies for ChIP analysis used in this study were anti-Flag M2 (F3165, Sigma), anti-RAR (M-454, Santa Cruz) and anti-RIPK1 (610458, BD Transduction Laboratories). At least 3 biological experiments were carried out and data are presented as means \pm s.d.

The following primer sequences for Chip assay were used:

\begin{tabular}{lll}
\hline Target gene & Forward primer sequence (5' to 3') & Reverse primer sequence (5' to 3') \\
\hline Rarb RARE & CTCTGGCTGTCTGCTTTTGC & CAGCTCACTTCCTACTACTTC \\
Cyp26al RARE & TAAAGATTTTGGGCAGCGCC & CATCTGCAAGGTTTCCCCAA \\
Gapdh promoter & TACTCGCGCTTTACGGG & TGGAACAGGGAGGAGCAGAGAGCA \\
\hline
\end{tabular}


bioRxiv preprint doi: https://doi.org/10.1101/156901; this version posted June 28,2017 . The copyright holder for this preprint (which was

not certified by peer review) is the author/funder, who has granted bioRxiv a license to display the preprint in perpetuity. It is made available under aCC-BY 4.0 International license.

Someda $\mathrm{M}$ et al.

Rescue experiments of $\operatorname{Casp}^{-/-}$embryos using an RA antagonist. BMS493 (Tocris

Bioscience) in DMSO $(100 \mathrm{mM})$ was diluted with olive oil to a final concentration of $3 \mu \mathrm{M}$

just before use. BMS493 (2.5 $\mu \mathrm{l} / \mathrm{g}$ of body weight; $7.5 \mathrm{pmol} / \mathrm{g}$ of body weight) was intraperitoneally injected into pregnant $\operatorname{Casp} 8^{+/-}$female mice intercrossed with $\operatorname{Casp} 8^{+/-}$male mice at E8.5, E9.5 and E10.5 after fertilization, and E11.5 Casp $^{-/-}$embryos were analyzed in comparison with $\operatorname{Casp} 8^{+/+}$littermates. 


\section{References}

1. Ablain, J., Rice, K., Soilihi, H., de Reynies, A., Minucci, S., and de The, H. (2014). Activation of a promyelocytic leukemia-tumor protein 53 axis underlies acute promyelocytic leukemia cure. Nat. Med. 20, 167-174.

2. Alvarez-Diaz, S., Dillon, C.P., Lalaoui, N., Tanzer, M.C., Rodriguez, D.A., Lin, A., Lebois, M., Hakem, R., Josefsson, E.C., O'Reilly, L.A., et al. (2016). The Pseudokinase MLKL and the Kinase RIPK3 Have Distinct Roles in Autoimmune Disease Caused by Loss of Death-Receptor-Induced Apoptosis. Immunity 45, 513-26.

3. Alnemri, E. (1997). Mammalian cell death proteases: a family of highly conserved aspartate specific cysteine proteases. J. Cell. Biochem. 64, 33-42.

4. Astrom, A., Pettersson, U., Chambon, P., and Voorhees, J.J. (1994). Retinoic acid induction of human cellular retinoic acid-binding protein-II gene transcription is mediated by retinoic acid receptor-retinoid $\mathrm{X}$ receptor heterodimers bound to one far upstream retinoic acid-responsive element with 5-base pair spacing. J. Biol. Chem. 269, 22334-22339.

5. Chinnaiyan, A.M., O'Rourke, K., Lane, B.R., and Dixit, V.M. (1997). Interaction of CED-4 with CED-3 and CED-9: a molecular framework for cell death. Science 275, 1122-1126.

6. Cortellino, S., Xu, J., Sannai, M., Moore, R., Caretti, E., Cigliano, A., Le Coz, M., Devarajan, K., Wessels, A., Soprano, D., et al. (2011). Thymine DNA glycosylase is essential for active DNA demethylation by linked deamination-base excision repair. Cell 146, 67-79.

7. Degterev, A., Huang, Z., Boyce, M., Li, Y., Jagtap, P., Mizushima, N., Cuny, G.D., Mitchison, T.J., Moskowitz, M.A., and Yuan, J. (2005). Chemical inhibitor of nonapoptotic cell death with therapeutic potential for ischemic brain injury. Nat. Chem. Biol. 1, 112-119.

8. Dillon, C.P., Weinlich, R., Rodriguez, D.A., Cripps, J.G., Quarato, G., Gurung, P., Verbist, K.C., Brewer, T.L., Llambi, F., et al. (2014) RIPK1 blocks early postnatal lethality mediated by caspase-8 and RIPK3. Cell 157, 1189-1202.

9. Dillon, C.P., Tummers, B., Baran, K., and Green, D.R. (2016). Developmental checkpoints 
guarded by regulated necrosis. Cell. Mol. Life Sci. 73, 2125-2136.

10. Dolle, P., Ruberte, E., Kastner, P., Petkovich, M., Stoner, C.M., Gudas, L.J., and Chambon, P. (1989). Differential expression of genes encoding alpha, beta and gamma retinoic acid receptors and CRABP in the developing limbs of the mouse. Nature 342, 702-705.

11. Duester, G. (2008). Retinoic acid synthesis and signaling during early organogenesis. Cell 134, 921-931.

12. Durand, B., Saunders, M., Leroy, P., Leid, M., and Chambon, P. (1992). All-trans and 9-cis retinoic acid induction of CRABPII transcription is mediated by RAR-RXR heterodimers bound to DR1 and DR2 repeated motifs. Cell 71, 73-85.

13. Green, D. (2005). Apoptotic pathways: ten minutes to dead. Cell 121, 671-674.

14. Harima, Y., Takashima, Y., Ueda, Y., Ohtsuka, T., and Kageyama, R. (2013). Accelerating the tempo of the segmentation clock by reducing the number of introns in the Hes7 gene. Cell Rep. 3, 1-7.

15. He, S., Wang, L., Miao, L., Wang, T., Du, F., Zhao, L., and Wang, X. (2009). Receptor interacting protein kinase-3 determines cellular necrotic response to TNF-alpha. Cell 137, 1100-1111.

16. Hitomi, J., Christofferson, D.E., Ng, A., Yao, J., Degterev, A., Xavier, R.J., and Yuan, J. (2008). Identification of a molecular signaling network that regulates a cellular necrotic cell death pathway. Cell 135, 1311-1323.

17. Horton, C., and Maden, M. (1995). Endogenous distribution of retinoids during normal development and teratogenesis in the mouse embryo. Dev. Dyn. 202, 312-323.

18. Itoh, N., Yonehara, S., Ishii, A., Yonehara, M., Mizushima, S., Sameshima, M., Hase, A., Seto, Y., and Nagata, S. (1991). The polypeptide encoded by the cDNA for human cell surface antigen Fas can mediate apoptosis. Cell, 66, 233-243.

19. Kaiser, W.J., Upton, J.W., Long, A.B., Livingston-Rosanoff, D., Daley-Bauer, L.P., Hakem, R., Caspary, T., and Mocarski, E.S. (2011). RIP3 mediates the embryonic lethality of caspase-8-deficient mice. Nature 471, 368-372. 
Someda $\mathrm{M}$ et al.

20. Kikuchi, M., Kuroki, S., Kayama, M., Sakaguchi, S., Lee, K.K., and Yonehara, S. (2012). Protease activity of procaspase- 8 is essential for cell survival by inhibiting both apoptotic and nonapoptotic cell death dependent on receptor-interacting protein kinase 1 (RIP1) and RIP3. J. Biol. Chem. 287, 41165-41173.

21. Kobayashi, Y., and Yonehara, S. (2009). Novel cell death by downregulation of eEF1A1 expression in tetraploids. Cell Death Differ. 16, 139-150.

22. le Maire, A., Teyssier, C., Erb, C., Grimaldi, M., Alvarez, S., de Lera, A.R., Balaguer, P., Gronemeyer, H., Royer, C.A., Germain, P., Bourguet, W. (2010). A unique secondary-structure switch controls constitutive gene repression by retinoic acid receptor. Nat. Struct. Mol. Biol. 17, 801-807.

23. Lee, S., Lee, B., Lee, J.W., and Lee, S.K. (2009). Retinoid signaling and neurogenin2 function are coupled for the specification of spinal motor neurons through a chromatin modifier CBP. Neuron 62, 641-654.

24. Lee, T.I., Johnstone, S.E., and Young, R.A. (2006). Chromatin immunoprecipitation and microarray-based analysis of protein location. Nat. Protoc. 1, 729-748.

25. Loudig, O., Babichuk, C., White, J., Abu-Abed, S., Mueller, C., and Petkovich, M. (2000). Cytochrome P450RAI(CYP26) promoter: a distinct composite retinoic acid response element underlies the complex regulation of retinoic acid metabolism. Mol. Endocrino. 14, 1483-1497.

26. Mandal, P., Berger, S.B., Pillay, S., Moriwaki, K., Huang, C., Guo, H., Lich, J.D., Finger, J., Kasparcova, V., Votta, B., et al. (2014). RIP3 induces apoptosis independent of pronecrotic kinase activity. Mol. Cell 56, 481-495.

27. Mangelsdorf, D.J., Ong, E.S., Dyck, J.A., and Evans, R.M. (1990). Nuclear receptor that identifies a novel retinoic acid response pathway. Nature, 345, 224-229.

28. Mangelsdorf, D.J., Umesono, K., Kliewer, S.A., Borgmeyer, U., Ong,, E.S., and Evans, R.M. (1991). A direct repeat in the cellular retinol-binding protein type II gene confers differential regulation by RXR and RAR. Cell, 66, 555-561.

29. Mark ,M., Ghyselinck, N.B., Chambon, P. (2005). Function of retinoid nuclear receptors: 
lessons from genetic and pharmacological dissections of the retinoic acid signaling pathway during mouse embryogenesis. Annu. Rev. Pharmacol. Toxicol. 46, 451-480.

30. Mattei, M.G., Riviere, M., Krust, A., Ingvarsson, S., Vennstrom, B., Islam, M.Q., Levan, G., Kautner, P., Zelent, A., Chambon, P., et al. (1991). Chromosomal assignment of retinoic acid receptor (RAR) genes in the human, mouse, and rat genomes. Genomics 10, 1061-1069.

31. Minamida, Y., Someda, M., and Yonehara, S. (2014). FLASH/casp8ap2 is indispensable for early embryogenesis but dispensable for proliferation and differentiation of ES cells. PLoS One 9, e108032.

32. Moutier, E., Ye, T., Choukrallah, M.A., Urban, S., Osz, J., Chatagnon, A., Delacroix, L., Langer, D., Rochel, N., Moras, D., et al. (2012) Retinoic acid receptors recognize the mouse genome through binding elements with diverse spacing and topology. J. Biol. Chem. 287, 26328-26341.

33. Muzio, M., Chinnaiyan, A. M., Kischkel, F. C., O’Rourke, K., Shevchenko, A., Ni, J., Scaffidi, C., Bretz, J. D., Zhang, M., Gentz, R., et al. (1996). FLICE, a novel FADD-homologous ICE/CED-3-like protease, is recruited to the CD95 (Fas/APO-1) death-inducing signaling complex. Cell 85, 817-827.

34. Oberst, A., Dillon, C.P., Weinlich, R., McCormick, L.L., Fitzgerald, P., Pop, C., Hakem, R., Salvesen, G.S., and Green, D.R. (2011). Catalytic activity of the caspase-8-FLIP(L) complex inhibits RIPK3-dependent necrosis. Nature 471, 363-367.

35. Ogura, T., and Evans, R.M. (1995). A retinoic acid-triggered cascade of HOXB1 gene activation. Proc. Natl. Acad. Sci. USA 92, 387-391.

36. Rhinn, M., and Dolle, P. (2012). Retinoic acid signalling during development. Development $139,843-858$.

37. Rossant, J., Zirngibl, R., Cado, D., Shago, M., and Giguere, V. (1991). Expression of a retinoic acid response element-hsplacZ transgene defines specific domains of transcriptional activity during mouse embryogenesis. Genes Dev. 5, 1333-1344.

38. Sakamaki, K., Inoue, T., Asano, M., Sudo, K., Kazama, H., Sakagami, J., Sakata, S., Ozaki, M., Nakamura, S., Toyokuni, S., et al. (2002). Ex vivo whole-embryo culture of 
caspase-8-deficient embryos normalize their aberrant phenotypes in the developing neural tube and heart. Cell Death Differ. 9, 1196-1206.

39. Salvesen, G. S., and Dixit, V. M. (1997). Caspases: intracellular signaling by proteolysis. Cell $91,443-446$.

40. Thornberry, N. A., and Lazebnik, Y. (1998). Caspases: enemies within. Science 281, 1312-1316.

41. Um, S., Harbers, M., Benecke, A., Pierrat, B., Losson, R., and Chambon, P. (1998). Retinoic acid receptors interact physically and functionally with the $\mathrm{T}: \mathrm{G}$ mismatch-specific thymine-DNA glycosylase. J. Biol. Chem. 273, 20728-20736.

42. Varfolomeev, E.E., Schuchmann, M., Luria, V., Chiannilkulchai, N., Beckmann, J.S., Mett, I.L., Rebrikov, D., Brodianski, V.M., Kemper, O.C., Kollet, O., et al. (1998). Targeted disruption of the mouse Caspase 8 gene ablates cell death induction by the TNF receptors, Fas/Apo1, and DR3 and is lethal prenatally. Immunity 9, 267-276.

43. Wang, H., Sun, L., Su, L., Rizo, J., Liu, L., Wang, L.F., Wang, F.S., and Wang, X. (2014). Mixed lineage kinase domain-like protein MLKL causes necrotic membrane disruption upon phosphorylation by RIP3. Mol. Cell 54, 133-146.

44. Wang, Z.Y., and Chen, Z. (2008). Acute promyelocytic leukemia: From highly fatal to highly curable. Blood 111, 2505-2515.

45. Watanabe, K., Kamiya, D., Nishiyama, A., Katayama, T., Nozaki, S., Kawasaki, H., Watanabe, Y., Mizuseki, K., and Sasai, Y. (2005). Directed differentiation of telencephalic precursors from embryonic stem cells. Nat. Neurosci. 8, 288-296.

46. Yang, Y., Ma, J., Chen, Y., and Wu, M. (2004). Nucleocytoplasmic shuttling of receptor-interacting protein 3 (RIP3): identification of novel nuclear export and import signals in RIP3. J. Biol. Chem. 279, 38820-38829.

47. Yonehara, S., Ishii. A., and Yonehara, M. (1989). A cell-killing monoclonal antibody (anti-Fas) to a cell surface antigen co-downregulated with the receptor of tumor necrosis factor. J Exp Med, 169, 1747-1756. 
bioRxiv preprint doi: https://doi.org/10.1101/156901; this version posted June 28, 2017. The copyright holder for this preprint (which was

not certified by peer review) is the author/funder, who has granted bioRxiv a license to display the preprint in perpetuity. It is made available under aCC-BY 4.0 International license.

Someda $\mathrm{M}$ et al.

48. Zelent, A., Krust, A., Petkovich, M., Kastner, P., and Chambon, P. (1989). Cloning of murine alpha and beta retinoic acid receptors and a novel receptor gamma predominantly expressed in skin. Nature 339, 714-717.

49. Zhang, D.W., Shao, J., Lin, J., Zhang, N., Lu, B.J., Lin, S.C., Dong, M.Q., and Han, J. (2009). RIP3, an energy metabolism regulator that switches TNF-induced cell death from apoptosis to necrosis. Science 325, 332-336. 
Someda $\mathrm{M}$ et al.

\section{Funding}

Grant-in-Aid for Scientific Research on Innovative Areas (Homeostatic regulation by various

types of cell death) (15H01376) from the Ministry of Education, Culture, Sports, Science and Technology (MEXT) of Japan.

Shin Yonehara

\section{Acknowledgments}

We thank J. A. Hejna for advice and critical reading of the manuscript, and all members of the

Yonehara laboratory for helpful discussions. We are grateful to Y. Harima, T. Ohtsuka and R.

Kageyama for in situ hybridization analyses. 